\title{
Revision of the South American freshwater fish genus Laemolyta Cope, 1872 (Ostariophysi: Characiformes: Anostomidae)
}

\author{
Kelly Cristina Mautari and Naércio Aquino Menezes
}

\begin{abstract}
The anostomid genus Laemolyta Cope, 1872, is redefined.Various morphological, especially osteological characters in addition to the commonly utilized features of dentition proved useful for its characterization. A taxonomic revision of all species was made using meristics, morphometrics and color pattern. Five species are recognized: Laemolyta fernandezi Myers, 1950, from the río Orinoco (Venezuela) and the sub-basins Tocantins/Araguaia and Xingu, L. orinocensis (Steindachner, 1879), restricted to the río Orinoco, L. garmani (Borodin, 1931) and L. proxima (Garman, 1890), from the Amazon basin with the latter also occurring in the Essequibo River (Guiana), and L. taeniata (Kner, 1859), from the Amazon and Orinoco basins. Laemolyta garmani macra is considered a synonym of $L$. garmani, L. petiti a synonym of $L$. fernandezi, and $L$. nitens and $L$. varia synonyms of L. proxima. Lectotypes are designated herein for L. orinocencis and L. taeniata.

O gênero Laemolyta Cope, 1872 da família Anostomidae é redefinido e além das características da dentição usualmente utilizadas, outros caracteres morfológicos, principalmente osteológicos, também se revelaram úteis para sua conceituação. Foi feita a revisão taxonômica de todas as espécies utilizando-se dados morfométricos, merísticos e padrão de colorido. Cinco espécies são reconhecidas: Laemolyta fernandezi Myers, 1950 do rio Orinoco (Venezuela) e rios Tocantins/Araguaia e Xingu, Laemolyta orinocensis (Steindachner, 1879) restrita ao rio Orenoco, L. garmani (Borodin, 1931) e Laemolyta proxima (Garman, 1890) da bacia Amazônica, esta última ocorrendo também no rio Essequibo (Guianas) e Laemolyta taeniata (Kner, 1859) da bacia Amazônica e rio Orenoco. Laemolyta garmani macra é considerada sinônimo de L. garmani, L. petiti sinônimo de $L$. fernandezi e L. nitens e L. varia sinônimos de L. proxima. São designados lectótipos de L. orinocencis e L. taeniata.
\end{abstract}

Key words: South America, Synonymy, Lectotype designation, Neotropica.

\section{Introduction}

The family Anostomidae has been recognized as a monophyletic assemblage by Vari (1983) primarily based on synapomorphies related to modifications of the gill apparatus and suspensorium, but the monophyletic nature of the included genera has not been demonstrated. A better morphological characterization of the species of Laemolyta is critical since the species in the genus have never been adequately described. The original descriptions are imprecise and based on a limited number of sometimes young specimens.

In this work the species of the genus Laemolyta are systematically reviewed and their osteological characters are analyzed and compared to those of other anostomid genera in order to find morphological characters other than dentition and mouth position to better characterize the genus. A phylogenetic analysis of characters was not attempted because this would require the examination of all anostomid genera and outgroups, an effort that extends far beyond the scope of this paper. The relationships of the species and a phyloge- netic definition of Laemolyta will be the subject of a subsequent paper.

\section{Material and Methods}

Counts and measurements were taken on the left side of the specimens, except when the structure being measured or counted was recognizably abnormal or damaged on that side. All measurements were taken point to point with calipers and data recorded to tenths of a millimeter. Head length and other parts of body are presented as percents of standard length and subunits of the head are presented as percents of head length. Greatest body depth was taken at dorsal-fin origin. Counts and measurements are presented in tables and were taken according to Fink \& Weitzman (1974), except for measurements involving the anterior delimiter of the specimen. In this study, they were always taken from the anterior end of the closed lower jaw rather than the premaxillary because of the upturned mouth in Laemolyta. Lateral-line scale count includes all perforated scales, even those posterior to the

Museu de Zoologia da USP, Caixa Postal 42494, 04218-970 São Paulo, SP, Brazil. 
hypural joint. Predorsal scales were counted only in species where the scale arrangement was regular. Total number of vertebrae includes the four vertebrae of the Weberian apparatus and the fused PU1 + U1 of the caudal fin which was considered as a single element. Vertebral counts were taken from radiographs of specimens and from specimens cleared and stained following the method of Taylor and Van Dyke (1985). In the meristic data, asterisks indicate values for holotype. In counts of fin rays, unbranched rays are indicated by lower case Roman numerals, and branched rays by Arabic numerals. Number of gill-rakers includes those of the dorsal and ventral limb of first gill arch, but with such counts taken only from a subset of specimens of each species because of the damage to some head bones that is inevitable in making this count accurately.

Teeth are described for each premaxilla and dentary, from the medial to lateral regions of the mouth. Thus, the sequence is first tooth (premaxillary) or symphyseal (dentary), second, third, and fourth teeth.

The material examined is listed by country and, then within each country data for each lot includes state, province or city, department or district, more precise locality data, institutional abbreviation, catalog number, number of specimens measured and counted in each lot, followed by the range of standard lengths. For type material collecting date and collector are added. Sex of specimens was determined by a macroscopic examination of the gonads. No sexual dimorphism was found in meristic and morphometric data and color pattern.

Institutional abbreviations are: ANSP - Academy of Natural Sciences of Philadelphia, Philadelphia; AMNH - American Museum of Natural History, New York; CAS - California Academy of Sciences, San Francisco; DZ-IBUSP - Departamento de Zoologia do Instituto de Biociências da Universidade de São Paulo, São Paulo; FMNH - Field Museum of Natural History, Chicago; INPA - Instituto Nacional de Pesquisas da Amazônia, Manaus; MBUCV - Museo de Biología de la Universidad Central de Venezuela, Caracas; MCNG - Museo de Ciencias Naturales de Guanare, Guanare; MCZ - Museum of Comparative Zoology, Cambridge; MHNG - Muséum d'Histoire Naturelle, Geneve; MHNLS - Museo de Historia Natural La Salle, Caracas; MNHN - Muséum National d'Histoire Naturelle, Paris; MZUSP - Museu de Zoologia da Universidade de São Paulo, São Paulo; NMW - Naturhistorisches Museum Wien, Vienna; NRM - Swedish Museum of Natural History, Stockholm; UMMZ - Museum of Zoology, University of Michigan, Ann Arbor; and USNM - National Museum of Natural History, (Smithsonian Institution), Washington D. C.

Specimens of Laemolyta fernandezi (INPA 12234, $94.4 \mathrm{~mm}$ $\mathrm{SL}$ ), L. garmani (MZUSP 32402, $155.9 \mathrm{~mm} \mathrm{SL}$ ), L. proxima (MZUSP 2105, $100.5 \mathrm{~mm} \mathrm{SL}$ ) and L. taeniata (MZUSP 29190, $81.4 \mathrm{~mm} \mathrm{SL}$ ) were cleared and stained for the osteological study and compared with cleared and stained specimens of the following species representing ten of the twelve recognized anostomid genera: Abramites hypselonotus (MZUSP 48123, $63.5 \mathrm{~mm}$ SL) Anostomoides laticeps (INPA 15193, 122.0 mm SL), Anostomus ternetzi (MZUSP 9990), Leporellus vittatus (MZUSP 20690, 80.0-81.8 mm SL), Leporinus striatus (no collecting data, $71.2 \mathrm{~mm} \mathrm{SL}$ ), Pseudanos trimaculatus (INPA 11816, $90.8 \mathrm{~mm} \mathrm{SL}$ ), Rhytiodus microlepis (INPA 16180, $99.0 \mathrm{~mm}$ SL), Schizodon fasciatus (MZUSP 62436, $55.8 \mathrm{~mm} \mathrm{SL}$ ), and Synaptolaemus cingulatus (INPA 10047, 77.2 mm SL).

For comparison of dentition and mouth position the following anostomid material was studied: Abramites hypselonotus (MZUSP 50424, 50423, 38161), Anostomoides laticeps (MZUSP 63019, 15799, 15773), Anostomoides sp. (MZUSP 8527, 6704; ANSP 136880), Anostomus anostomus (MZUSP 31061, 29160, 21448), A. plicatus (MZUSP 38228), A. ternetzi (MZUSP 52131, 5161, 35997, 9989, 36029, 21366), Gnathodolus bidens (INPA 10089), Leporellus vittatus (MZUSP 59672, 42909, 42907, 20690), Leporellus sp. (MZUSP 63676), L. cf. acutidens (MZUSP 44345), Leporinus affinis (MZUSP 54457), L. agassizi (MZUSP 29211, 29217, 29209), L. (MZUSP 35638), L. amblyrhynchus (MZUSP 66216, 42947), L. aripuanensis (MZUSP 60394), L. bahiensis (MZUSP 2823), L. bistriatus (MZUSP 59276), L. brunneus (MZUSP 47834), L. conirostris (MZUSP 43805, 47890), L. copelandii (MZUSP 47904, 52561), L. elongatus (MZUSP 48810, 48837, 25606), L. friderici (MZUSP 48395, 48391), L. macrocephalus (MZUSP 38852), L. maculatus (MZUSP 48830) L. nijsseni (MZUSP 48506), L. lacustris (MZUSP 43024), L. melanopleura (MZUSP 3825), L. cf. marcgravii (MZUSP 41837), L. mormyrops (MZUSP 1750), L. multifasciatus (MZUSP 48423) L. obtusidens (MZUSP 48425), L. octofasciataus (MZUSP 43096), L. pachycheilus (MZUSP 29175), L. parae (MZUSP 48445), L. paranensis (MZUSP 36777), L. pellegrini (MZUSP 32374 , 29185), L. piau (MZUSP 39395), L. reinhardti (MZUSP 39415, 54670), L. silvestri (MZUSP 48466) L. steindachneri (MZUSP 3443), L. striatus (MZUSP 59532), L. taeniatus (MZUSP 54662, 28776), L. trifasciatus (MZUSP 6523), L. unitaeniatus (MZUSP 54541), Leporinus sp. (MZUSP 29132, 62433, 47801), Pseudanos gracilis (MZUSP 21159, 21061, 31252, 29165, 29166), P. trimaculatus (MZUSP 29159, 31476, 31441, 35581, 36927), P. sp. (MZUSP 29164, 29161,35765, 29168, 21159,31255, 29163, 56304), Rhytiodus argenteofuscus (MZUSP 56806), $R$. elongatus (MZUSP 5622), R. microlepis (MZUSP 56939, INPA 16180, 6962), $R$. sp. (MZUSP 62441, 5906, FMNH 102131, NRM 25990), Sartor elongatus (MZUSP 38578), S. tucuruiensis (MZUSP 38579), Schizodon altoparanae (MZUSP 53849), S. australis (MZUSP 1385), S. borelli (MZUSP 48300), 62439, 36360), S. fasciatus (MZUSP 50432, 7518, 21263, 62435, 26262), S. knerii (MZUSP 47326), S. intermedius (MZUSP 20778), S. isognathus (MZUSP 38167, 52533), S. nasutus (MZUSP 53861, 47758), S. vittatus (MZUSP 53727), S. platae (MZUSP 47691), Schizodon. sp. (MZUSP 3583, 5424, MCNG 18968, USNM 258159), and Synaptolaemus cingulatus (MZUSP 63054).

\section{Laemolyta Cope, 1872}

Laemolyta Cope, 1872: 258. Type species: Schizodon taeniatus Kner, 1859, by monotypy; Eschmeyer, 1998: 1986 [catalog]; Garavello \& Britski, 2003: 72 [catalog]. 
Schizodontopsis Garman, 1890 subgenus of Anostomus. Type species: Schizodon taeniatus Kner, 1859, type by subsequent designation (Eigenmann, 1910: 425); Eschmeyer, 1998: 2121 [catalog]; Garavello \& Britski, 2003: 72 [catalog].

Diagnosis. Laemolyta is distinguished from all other genera of the Anostomidae in having the symphyseal tooth of the dentary approximately equal in size to the second tooth with both teeth spatulated, very compressed, and with the upper edge straight ( $v s$. symphyseal tooth sometimes much larger than the second tooth or slightly larger than the second tooth and sometimes cusped as the remaining dentary teeth, thick or recurved) (Fig. 1). Adult specimens have a supra-terminal mouth, a condition that is shared only with Anostomoides among anostomids. In spite of Winterbottom's interpretation of a supraterminal mouth in the Anostominae, in our interpretation all members of this subfamily have a superior mouth. Species of Anostomoides, however, have the symphyseal tooth longer than the second tooth on the dentary. Laemolyta further differs from all other examined genera of the Anostomidae in possessing a protuberance on the anteroventral region of the ectopterygoid (Fig. 2), in the elongated mesopterygoid (Fig. 2) with a small ventrally-directed process on its lateral surface and its ventral margin poorly developed, and in the relatively wide premaxilla with a fold on its median ventral margin that is prolonged as a rounded process medially, the upper premaxillary margin slightly recurved (Fig. 3).

Popular name. Piaus and Aracus.

Distribution. Amazon, Essequibo, and Orinoco basins.

Remarks. Five species are recognized within Laemolyta in this study: L. fernandezi Myers (1950), L. garmani (Borodin, 1931), L. orinocensis (Steindachner, 1879), L. proxima (Garman, 1890), and L. taeniata (Kner, 1859).

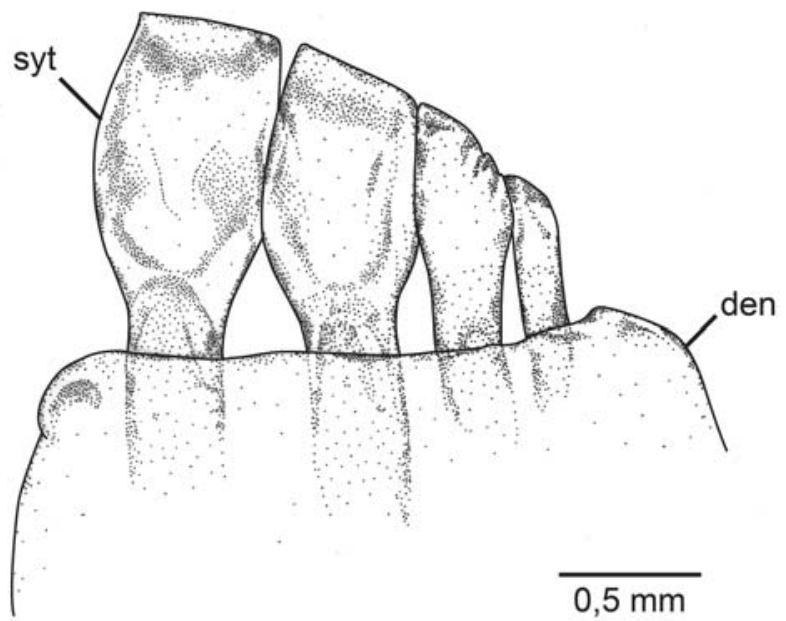

Fig. 1. Dentary teeth (den) of Laemolyta fernandezi, INPA 12234, $93.7 \mathrm{~mm} \mathrm{SL}$, left side, frontal view; syt = symphyseal tooth.

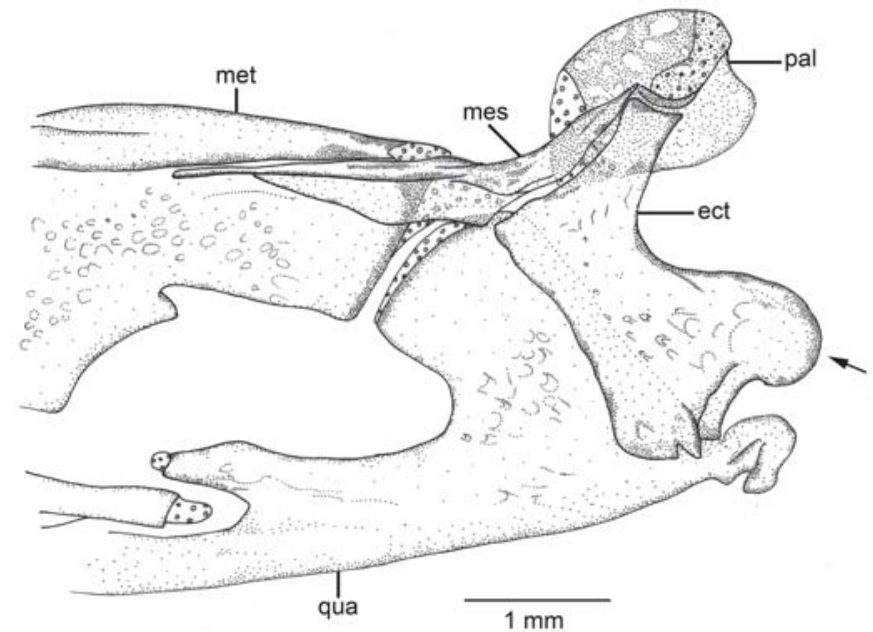

Fig. 2. Anterior region of suspensorium of Laemolyta fernandezi, INPA 12234, $93.7 \mathrm{~mm}$ SL, left side, medial view; ect $=$ ectopterygoid, met $=$ metapterygoid, mes $=$ mesopterygoid, pal $=$ palatine, qua $=$ quadrate. Arrow indicates protuberance on anteroventral region of ectopterygoid.

Cope (1872), described the genus Laemolyta to include Schizodon taeniatus Kner, 1859, that according to him differed from the remaining species of Schizodon known at the time in which the branchiostegal membranes were entirely free from the isthmus, the dentary teeth truncate with their

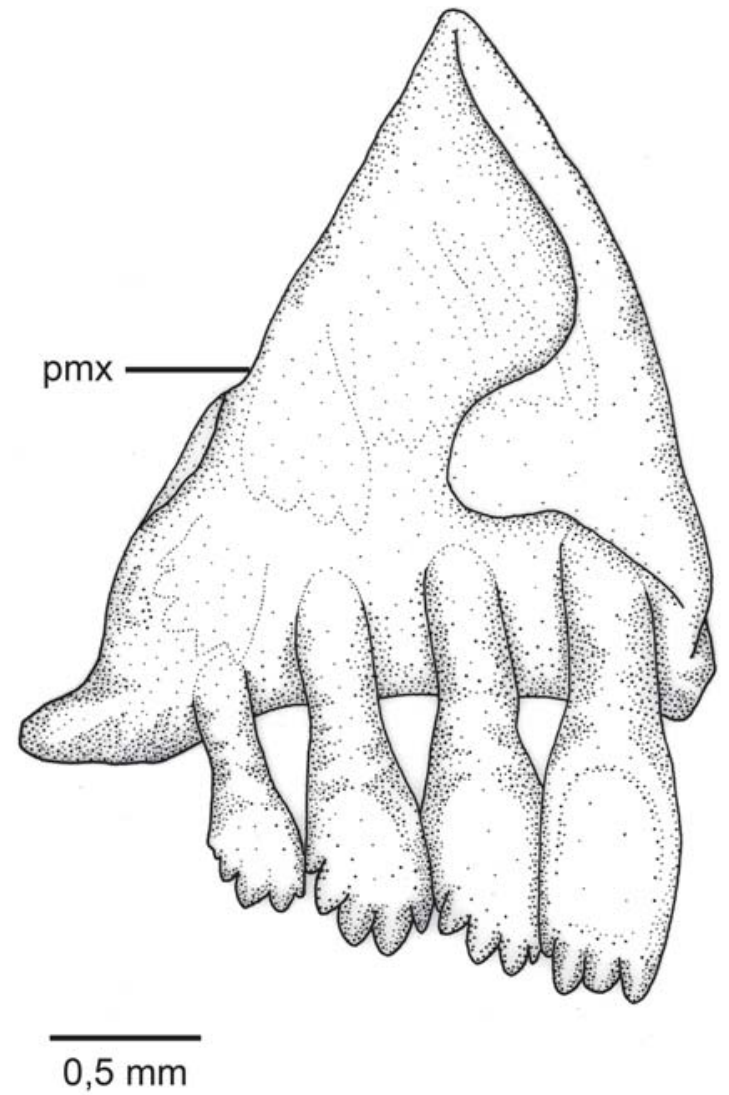

Fig. 3. Premaxillary (pmx) of Laemolyta fernandezi, INPA 12234, $93.7 \mathrm{~mm}$ SL, left side, medial view. 
upper edge entire and premaxillary teeth crenate. The typespecies of the genus, Laemolyta taeniata, had been first described in Schizodon by Kner (1859) but was later included in Anostomus by Günther (1864).

In his study of the genus Anostomus, Garman (1890) recognized three groups or sub-genera based primarily on the snout shape, position of the mouth opening, and form of dentition: Anostomus, Schizodontopsis, and Schizodon. Schizodontopsis (=Laemolyta) was primarily characterized by having its mouth aligned obliquely forward and upturned and by the lower jaw bearing large truncate teeth with their upper edges straight. He described two species that he assigned to this group: Anostomus (Schizodontopsis) proximus and Anostomus (Schizodontopsis) varius and considered Anostomus (Schizodontopsis) nitens to be a "variation" of Anostomus (Schizodontopsis) varius.

Eigenmann \& Eigenmann (1891) listed in Laemolyta the species that Garman (1890) considered to belong in the subgenus Schizodontopsis and others including $L$. taeniata, $L$. proximus, $L$. varius, $L$. varius nitens, and $L$. orinocensis. Subsequently, however, Eigenmann (1910) included only the typespecies of the genus Schizodon taeniatus Kner, 1859 in Laemolyta; and allocated the other species previously included in this genus to Anostomus. In the same paper Eigenmann considered the sub-genus Schizodontopsis Garman, 1890 to be synonymous with Laemolyta.

Myers (1950) retained Schizodontopsis Garman (1890) in the synonymy of Laemolyta and based on Garman (1890), Borodin (1931), and Steindachner (1879) prepared a list of eight species of Laemolyta: L. fasciata Pearson, 1924, L. garmani (Borodin, 1931), L. nitens (Garman, 1890), L. proxima (Garman, 1890), L. taeniata (Kner, 1859), and L. varia (Garman, 1890) all from the Amazon basin, L. orinocensis (Steindachner, 1879) from the río Orinoco basin and L. laticeps (Eigenmann, 1912) from Guiana. Additionally, he described Laemolyta fernandezi, based on a $72.5 \mathrm{~mm}$ SL juvenile collected in the upper río Orinoco. Myers noted that in Laemolyta the branchiostegal membranes are in actuality closely connected to the isthmus, contrary to what was reported by Cope (1872). Myers also distinguished Laemolyta from Schizodon, mainly by dentition, with Laemolyta having the dentary teeth truncate with their upper edges straight whereas Schizodon has cuspidate teeth on both jaws.

Fowler (1950) included in Laemolyta all species recognized by Myers (1950), with the exception of $L$. laticeps and $L$. orinocensis, and added L. borellii (Boulenger, 1900) of the rio Paraguay basin to the genus. The form of dentition described by Cope (1872) and Myers (1950) for Laemolyta was observed in all of the species listed above, except for $L$. fasciata, L. borellii and L. laticeps.

Laemolyta fasciata was described by Pearson (1924) based on two immature specimens ( $20 \mathrm{~mm} \mathrm{SL}$ ) from Bolivia with the taxonomic position of the species becoming very confused when Ahl (1937) shifted the species to Anostomus. Ahl reported that Laemolyta fasciata possessed the characteristics of Anostomus (Schizodontopsis) Garman, 1890 as a con- sequence of the fact that he did not recognize Garman's subgenera. Since Anostomus fasciatus was already preoccupied in Anostomus (Spix \& Agassiz, 1829), Ahl renamed the species described by Pearson as Anostomus pearsoni. Myers (1950) did not recognize Ahl's combination as valid, because according that author the name fasciatus was not occupied in Laemolyta.

The type material of Laemolyta fasciata was not examined during this study but all measurements and counts on that specimen were taken by Anostomoides Mônica ToledoPiza (DZ-IBUSP) and the digitalized picture and radiograph of the specimen were provided by David Catania (CAS). This information was insufficient to permit a definitive identification because the specimen is a juvenile $(15.7 \mathrm{~mm} \mathrm{SL})$ in very poor condition. According to H. A. Britski (MZUSP) (pers. commun.) the general characteristics of the specimen, in particular its color pattern suggest that this specimen might belong to a species of Leporinus. Böhlke (1958) discussed this question and if this is true, the valid combination would become Leporinus pearsoni (Ahl, 1937), which would be a homonym of Leporinus pearsoni Fowler, 1940. The problem about the correct name for the species in question can only be resolved after a more detailed study.

Laemolyta borellii (Boulenger, 1900) included by Fowler (1950) in that genus, has teeth with five or six cusps of about the same size on both jaws, a characteristic of the genus Schizodon according to Garavello \& Britski (1990) and Garavello (1994).

Laemolyta laticeps cited by Borodin (1931) and Myers (1950) belongs to Anostomoides Pellegrin, 1908, as suggested by Géry (1974: 149, in footnote). Géry examined the type and mentioned that it was very similar to Anostomoides atrianalis. One of us (KCM) examined the holotype of Schizodontopsis laticeps Eigenmann, 1912 and confirmed that it is not a species of Laemolyta. The lower jaw teeth of the specimen have rounded upper margins and the symphyseal tooth is considerably more developed than the second tooth, both of which are characteristic of Anostomoides.

According to Géry (1977) the genus Anostomus is composed of two groups that could be considered distinct genera or subgenera: Anostomus (Laemolyta) and Anostomus (Anostomus). The Laemolyta group is distinct in having the mouth opening slightly less upturned (not quite aligned with the dorsal surface of the snout), and in having multicuspidate teeth on the premaxilla and truncate teeth on the dentary. Géry also emphasized the great similarity between the dentition of young specimens of Laemolyta and Anostomus and the manner in which they orient in the water column with the head downturned.

In young specimens of Laemolyta the premaxillary teeth are very similar to those of adult specimens of Anostomus, and it was probably for this reason that Géry considered Laemolyta to be a sub-genus of Anostomus. The supra-terminal mouth is not useful to distinguish young specimens of Laemolyta from some other anostomids. According to H. A. Britski (MZUSP) (pers. commun.) young specimens of some 
Leporinus species have such a form of the mouth. According to Winterbottom's (1980) phylogenetic analysis of the members of the subfamily Anostominae the inclusion of Laemolyta in Anostomus is not justifiable since Anostomus is a monophyletic group within the subfamily, with Laemolyta proposed as the possible sister-group to the Anostominae.

Specimens over $40 \mathrm{~mm}$ SL can be identified as members of Laemolyta by the presence of crenate teeth on the upper jaw and the possession of compressed teeth with a straight apical margin. In specimens smaller than $40 \mathrm{~mm}$ SL the teeth both on the upper and lower jaws are cuspidate which makes identification to the generic level based on dentition very difficult.

\section{Key to the species of Laemolyta}

1. Four or five longitudinal series of scales above lateral line; well defined midlateral dark stripe always present on body; transverse dark bars absent; dark spot on caudal peduncle absent

1'. Six to eight longitudinal series of scales above lateral line; midlateral dark stripe, conspicuous or not; transverse dark bars or blotches, well defined or inconspicuous; peduncular dark spot present or absent

2. Five longitudinal series of scales above lateral line and four or five below it; 42-46 lateral line scales

Laemolyta taeniata

2'. Four longitudinal series of scales above and below lateral line; 40-44 lateral line scales ........... Laemolyta garmani

3. 43 to 47 lateral line scales; 16 scales around caudal peduncle Laemolyta proxima

3'. 47 to 58 lateral line scales; $16-20$ scales around caudal peduncle. ... 4

4. Midlateral dark stripe usually conspicuous; transverse dark bars very inconspicuous; dark spot absent on caudal peduncle; 6 longitudinal series of scales below lateral line; 47 to 52 lateral line scales; body depth $0.21-0.25$ of SL ................................................ Laemolyta orinocensis

4'. Midlateral dark stripe sometimes inconspicuous; four transverse dark bars or blotches present; dark spot usually present on caudal peduncle; 5-7 longitudinal series of scales below lateral line; 49 to 58 lateral line scales; body depth $0.23-0.32$ of SL Laemolyta fernandezi

\section{Laemolyta fernandezi (Myers, 1950)} Fig. 4

Laemolyta fernandezi Myers, 1950: 197, 198, [original description, type locality: upper Orinoco]; Géry, 1964: 466 [key to species]; Géry, 1974: 157-159, Fig. (3), p. 158 [complementary description, key to species]; Böhlke, 1953: 197 [catalog of types]; Eschmeyer, 1998: 574 [catalog]; Garavello \& Britski, 2003: 73 [catalog]; Taphorn et al., 1997:55-100 [catalog]; Lasso et al., 2004:105-195 [list of species and distribution].

Laemolyta petiti Géry, 1964: 464, plate IV b [type locality: ilha do Bananal, upper rio Araguaia]; Santos \& Jégu, 1989:
166, Fig. p. 196 [redescription]; Santos et al., 1984: 33 [lower rio Tocantins]; Eschmeyer, 1998: 1326 [catalog]; Garavello \& Britski, 2003: 73 [catalog].

Anostomus (Laemolyta) fernandezi: Géry, 1977: 180 [key to species, distribution].

Material examined. 93 specimens (63.6-212.9 mm SL). Venezuela. Río Orinoco system, upper Orinoco, 1925, C. Ternetz, CAS 116126, holotype, $73.1 \mathrm{~mm}$ SL. Anzoategui, río Orinoco basin, ANSP 166730, 5, 80.2-152.6 mm SL. Bolivar, río Orinoco basin, San Pedro de Tauca, ANSP 166532,1, 137.0 mm SL. Bolivar, laguna Aricagua, floodplain, río Caura, Vispo Conrad, MHNLS 13061, 1 of 2, $110.9 \mathrm{~mm}$ SL. Bolivar, laguna Guaiparo, San Felix, MHNLS 7063, 1 of 3, $102.6 \mathrm{~mm}$ SL. Delta Amacuro, caño Guarguapo, in small tributary, approximately $500 \mathrm{~m}$ from mouth in río Orinoco, MZUSP 62448, 2, 80.6-109.8 mm SL. Brazil. Tocantins: upper rio Araguaia, ilha do Bananal, MHNG 2229.01,1, 74.8 mm SL. Pará: Itupiranga, Tocantins, INPA 1546, 4, 136.1-166.6 mm SL, INPA 1548, 5, 137.8-156.7 mm SL, INPA 1888, 1, 141.5 mm SL. Rio Tocantins, Icangui, Projeto Tucuruí, INPA 1547, 7, 95.1-141.7, INPA 12234, 14, 81.8-136.5 mm SL, INPA 15350, 6, 110.8-162.2 mm SL. Rio Tocantins below dam, Tucuruí, INPA 1549, 4, 168.3191.1 mm SL, INPA 16176, 2, 134.1-164.2 mm SL. Rio Tocantins, poço do Paulo, below Tucuruí Dam, INPA 1889, 2, 87.5-89.3 mm SL. Rio Tocantins, Jatobal, above Tucuruí Dam, INPA 1890, 2, 183.2-183.8 mm SL. Rio Tocantins, Tucuruí market, INPA 1891, 2, 193.4-201.3 mm SL. Rio Tocantins, INPA 15295, 2, 152.9191.3 mm SL. Rio Tocantins, reservoir above Tucuruí Dam, INPA 16176, 2, 134.1 and 164.2. Rio Tocantins, lago Tauá below Tucuruí, INPA 16177, 7, 132.5-156.3 mm SL. Base I of Tucuruí reservoir, INPA 16178, 5, 161.7-193.7 mm SL. Base IV of Tucuruí reservoir, INPA 16179, 2, 198.3-208.7 mm SL. Rio Xingu, Belo Monte, MZUSP 60180, 3, 172.8-212.9 mm SL, MZUSP 60181, 4, 163178.7 mm SL. MZUSP 61947, 1, 164.9 mm SL. Mato Grosso: rio Araguaia, Santa Terezinha, MZUSP 20842, 7, 63.6-110.3 mm SL.

Diagnosis. Laemolyta fernandezi is distinguished from all congeners by its deeper body (22.9-31.6\% vs. 17.2-29.8\%, respectively, Fig. 5). It can be further distinguished from all Laemolyta species, except $L$. orinocensis, by having more lateral line scales (49-58 vs. 40-47). Although L. fernandezi cannot be separated from $L$. orinocensis on the basis of this character, the latter species has a very conspicuous midlateral dark stripe, whereas in L. fernandezi this stripe is inconspicuous and the transverse dark spots are much more evident than in L. orinocensis.

Description. Morphometric and meristic data presented in Table 1. Body moderately large $(\mathrm{SL}=63.6-212.9 \mathrm{~mm})$. Dorsal profile of body straight or slightly concave from snout tip to

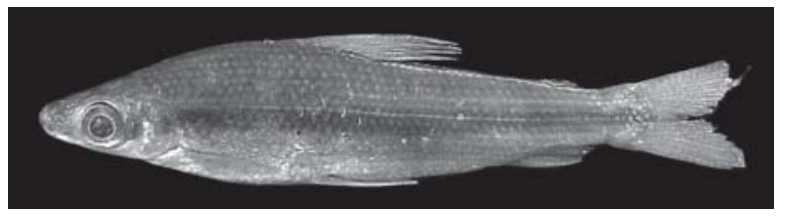

Fig. 4. Laemolyta fernandezi, CAS 116126, holotype, 73.1 mm SL; Venezuela, upper río Orinoco. 


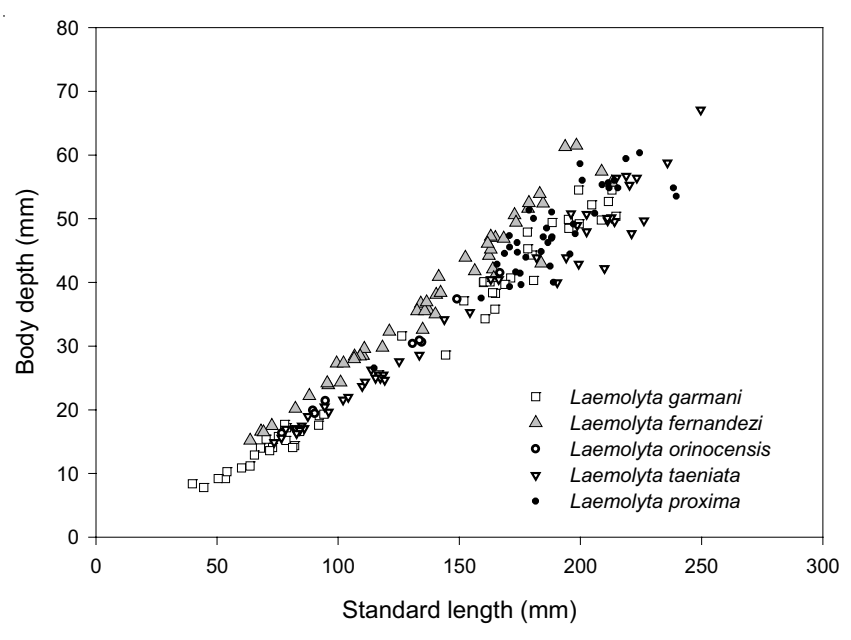

Fig. 5. Scatter plot of body depth on standard length for all species of Laemolyta.

end of supraoccipital spine, slightly convex from that point to origin of dorsal fin, straight and posteroventrally aligned along dorsal-fin base and straight or slightly convex from base of posterior most dorsal-fin ray to caudal peduncle. Ventral profile of body straight or slightly convex from anterior tip of lower jaw to region near isthmus and slightly convex from that point to anal-fin origin and slightly concave at region of pelvic-fin insertion. Upper limb gill-rakers 9-12 on first gill arch and 11-15 on lower limb.

Scales small, 49-58 (51*, usually 53, Table 2$)$ perforated along all of lateral line. Longitudinal scale rows from lateral line to dorsal-fin origin 7-8 ( $8^{*}$, usually 8$)$, scale rows from lateral line to anal-fin origin 5-7 ( $7^{*}$, usually 6$)$. Predorsal scales irregularly arranged. Scales rows around caudal peduncle 17-20 (19*, usually 18).

Dorsal fin rays ii, $10-12\left(10^{*}\right.$, usually 11$)$; distal margin of fin slightly rounded. Anal fin short, slightly falcate, with ii-iii (iii, rarely), $8-10\left(8^{*}\right.$, rarely 10$)$ rays. Pectoral fin rays i, 11-15 $(14 *$, usually 14$)$. Pelvic fin rays i, 8 ; distal margin of fin truncate. Vertebrae $39-42\left(42^{*}\right.$, usually $\left.39, \mathrm{~N}=30\right)$.

Color in alcohol. Adult specimens usually with dark, but sometimes very inconspicuous, longitudinal stripe, covering 1.5 to almost 3 longitudinal scale rows. Stripe extends from posterior region of opercle to caudal peduncle where it usually ends in form of darker triangular or oval spot. Upper region of body usually dark, with dark coloration extending ventrally to below midlateral dark stripe. Ventral region of body unpigmented from ventral limit of dark midlateral stripe on body to midventral one. Body with 4 transverse dark but sometimes inconspicuous bars or blotches, sometimes inconspicuous. First series situated between opercle and dorsal fin, but closer to opercle; second below dorsal fin, and usually more conspicuous; third located between pelvic and anal fins and last, anterior to adipose fin. First and second series usually more conspicuous and last series usually diffuse (Fig. 6).

Young specimens (Fig. 7) with midlateral longitudinal stripe indistinct, extending from anterior part of snout to rear of caudal peduncle and usually finishing in form of triangular spot. Four transverse bars or blotches present in adults absent. Upper part of body sometimes with approximately 14 narrow transverse dark bars extending ventrally to near lateral line. Adult specimens sometimes retain faded transverse bars. Adult specimens from río Orinoco basin (Fig. 8) with bars faded and midlateral longitudinal stripe on body very conspicuous.

Dorsal, pectoral, and ventral fins hyaline with scattered dark chromatophores. Dark chromatophores also scattered along fin margin and over median rays of caudal fin. Adipose fin usually dark.

Some specimens with 4 transverse dark bars quite evident, with dark blotch present on caudal peduncle and dark midlateral stripe on body faded (Fig. 9).

\section{Common name: Venezuela: Mije (Lasso, 1992).}

Distribution: Río Orinoco and Amazon basin (rios Xingu, Tocantins and Araguaia) (Fig. 10).

Remarks. Laemolyta fernandezi Myers, 1950, was described based on a young specimen (73.1 mm SL), that was considered to be a new species in having a compressed body and more longitudinal scale rows (8/7) than L. garmani, L. proxima and L. taeniata (4-6/4-7). According to Myers the specimen was collected in the upper río Orinoco, but the precise locality was not provided.

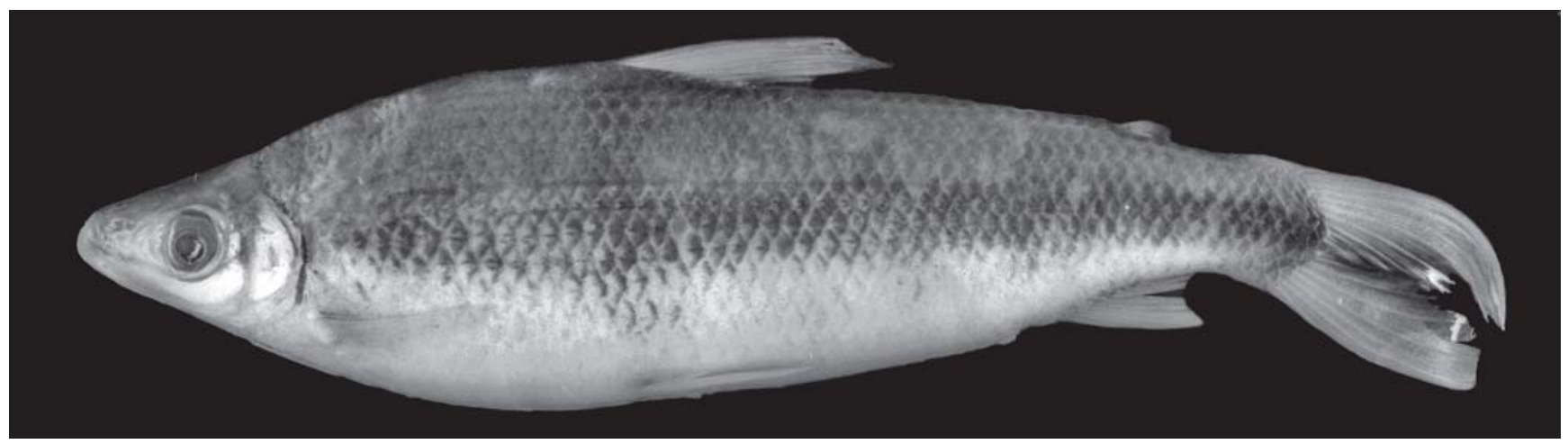

Fig. 6. Adult specimen of Laemolyta fernandezi, INPA 16178, 173.4 mm SL; Brazil, Pará, Base I Tucuruí Reservoir. 


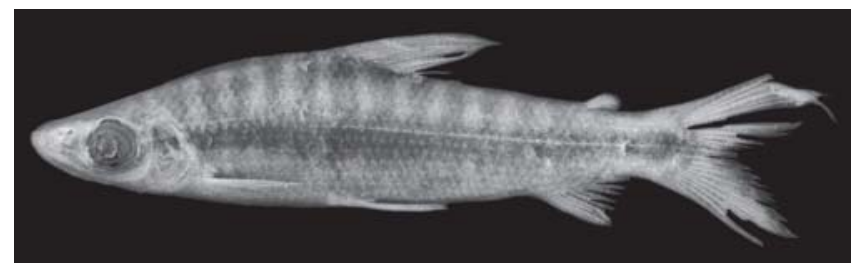

Fig. 7. Young specimen of Laemolyta fernandezi, MZUSP 20842, 63.6 mm SL; Brazil, Mato Grosso, rio Araguaia, Santa Terezinha.

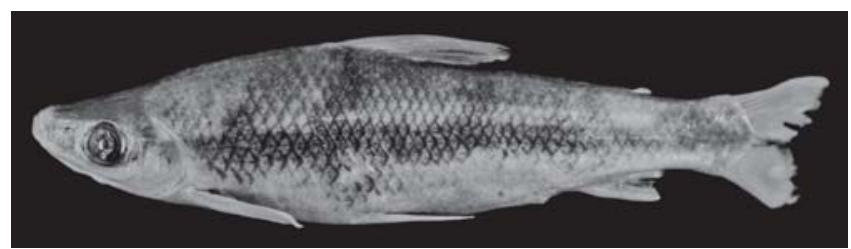

Fig. 8. Adult specimen of Laemolyta fernandezi, ANSP 166532 , 137 mm SL; Venezuela, Bolivar, rio Orinoco basin, San Pedro de Tauca, L. Madera.

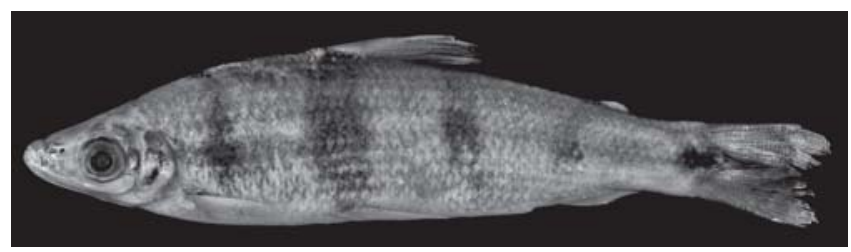

Fig. 9. Adult specimen of Laemolyta fernandezi, INPA 16177, 156.3 mm SL; Brazil, Pará, rio Tocantins, Lago Tauá below Tucuruí.

The description of L. petiti Géry, 1964, is also based on a young specimen $(76.4 \mathrm{~mm} \mathrm{SL})$, collected in the rio Araguaia. When Géry (1964) described his new species he recognized its similarity with $L$. fernandezi, but noted that a comparison between the two nominal forms was impossible because of the succinct description and lack of illustration of L. fernandezi. Later on Géry (1974) redescribed $L$. fernandezi and compared the data he obtained with those of $L$. petiti and found that $L$. fernandezi has fewer longitudinal scale rows $\left(7-7 \frac{1}{2} / 6-6 \frac{1}{2}\right)$, more lateral line scales (55) and a deeper caudal-peduncle than did L. petiti.

The comparison of meristic and morphometric data among specimens of L. fernandezi from the Orinoco, Tocantins/ Araguaia and rio Xingu basins revealed no significant differences between these populations. The number of vertebrae in a sample from the río Orinoco is 41 (10 specimens) and 42 (1 specimen - holotype) and from the rios Tocantins/Araguaia 39 ( 15 specimens), 40 ( 3 specimens) and 41 (1 specimen). The number of vertebrae in 4 specimens from the rio Xingu basin is 39 ( 1 specimen), 40 ( 2 specimens) and 41 ( 1 specimen). The comparison of body depth, that seemed to be visually different among the populations originating from the three basins mentioned, also did not show any significant difference (Fig. 11).

In spite of the slight difference in number of vertebrae we

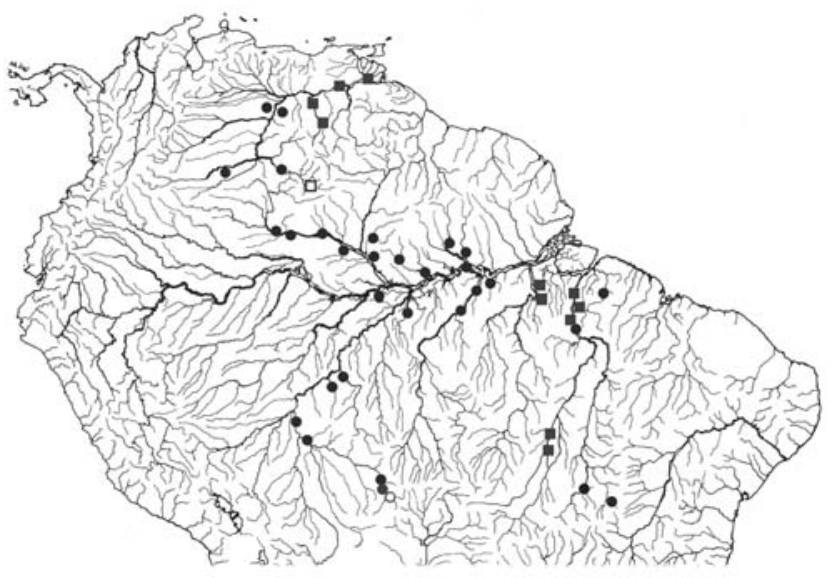

Fig. 10. Geographic distribution of Laemolyta taeniata (black dots; open circle = type-locality) and of Laemolyta fernandezi (black squares; open squares $=$ type-locality).

prefer to recognize just one widely distributed species represented by allopatric populations, especially because no other meristic or morphometric differences were found to distinguish the populations.

Laemolyta fernandezi was recorded from the rios Tocantins and Araguaia by Santos \& Jégu (1989) and is the most common anostomid species in the lower rio Tocantins (Santos et al., 1984). It is to date the only species of Laemolyta found in the central portion of the rio Araguaia basin. In the lower rio Araguaia it occurs in sympatry with L. garmani.

Laemolyta fernandezi reaches $25 \mathrm{~cm} \mathrm{SL}$ and eats small invertebrates (Santos \& Jegú, 1989), vegetable material and periphiton (Santos et al., 1984). Sexual maturity seems to occur in specimens at approximately $130 \mathrm{~mm}$ SL judging from direct observation of the gonads. Reproduction seems to occur during the flood season (Santos et al., 1984).

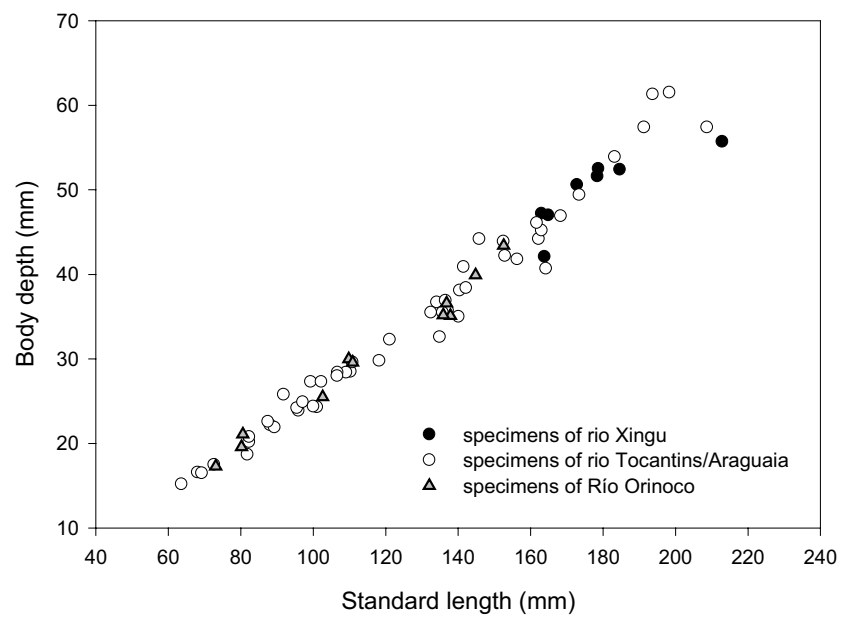

Fig. 11. Scatter plot of body depth on standard length for populations of Laemolyta fernandezi. 
Table 1. Morphometrics of Laemolyta fernandezi.

\begin{tabular}{|c|c|c|c|c|c|}
\hline Character & Holotype & $\mathrm{N}$ & Range & Mean & SD \\
\hline Standard length (mm) & 73.1 & 91 & $63.6-212.9$ & 134.2 & - \\
\hline \multicolumn{6}{|c|}{ Percents of standard length } \\
\hline Preanal distance & 77.6 & 91 & $77.8-85.2$ & 80.4 & 1.00 \\
\hline Preventral distance & 46.4 & 91 & $45.2-51.6$ & 48.3 & 1.23 \\
\hline Prepectoral distance & 25.4 & 91 & $20.6-26.7$ & 23.4 & 1.24 \\
\hline Predorsal distance & 45.1 & 91 & $42.8-46.7$ & 44.6 & 1.83 \\
\hline Body depth & 23.7 & 91 & $22.9-31.6$ & 27.2 & 2.00 \\
\hline Caudal-peduncle depth & 9.30 & 91 & $9.10-11.0$ & 10.2 & 0.41 \\
\hline Caudal-peduncle length & 14.5 & 91 & $9.70-14.5$ & 11.8 & 0.85 \\
\hline Dorsal-fin length & 26.8 & 91 & $22.5-29.2$ & 25.9 & 1.40 \\
\hline Ventral-fin length & 18.6 & 91 & $14.7-19.3$ & 17.1 & 0.93 \\
\hline Pectoral-fin length & 17.6 & 91 & $15.6-18.9$ & 17.5 & 0.81 \\
\hline Anal-fin length & 13.1 & 91 & $9.50-14.3$ & 12.6 & 0.81 \\
\hline Head length & 24.1 & 91 & $19.8-25.0$ & 23.0 & 0.88 \\
\hline Dorsal-fin base length & 14.9 & 91 & $12.5-31.0$ & 14.7 & 1.80 \\
\hline Anal-fin base length & 10.5 & 91 & $7.30-10.6$ & 8.90 & 0.63 \\
\hline \multicolumn{6}{|c|}{ Percents of head length } \\
\hline Eye diameter & 37.5 & 91 & $26.1-39.0$ & 32.0 & 2.30 \\
\hline Antorbital length & 34.1 & 91 & $32.6-42.2$ & 37.7 & 2.03 \\
\hline Interorbital distance & 39.8 & 91 & $36.8-49.8$ & 43.3 & 2.65 \\
\hline Body width opercle & 49.4 & 91 & $50.0-63.9$ & 56.5 & 3.15 \\
\hline
\end{tabular}

\section{Laemolyta garmani (Borodin, 1931)}

Fig. 12

Anostomus (Schizodontopsis) garmani Borodin, 1931: 47-48 [original description, type locality: Jutahy (Jutaí), Içá, Lake Hyavary (Lago Javarí)].

Laemolyta garmani: Myers, 1950: 197 [diagnosis, type locality]; Fowler, 1950: 208 [synonymy, distribution]; Géry, 1974: 152-153, 159 [description and identification key]; Ortega \& Vari 1986: 12 [catalogue]; Garavello \& Britski, 2003: 73 [catalog].

Laemolyta taeniata garmani: Géry, 1964: 466 [identification key]. Laemolyta garmani macra Géry, 1974: 153-154, fig. (2), p. 154 [original description, type locality: rio Nacuray, identification key]; Weber, 1998: 8 [catalog of fishes]; Eschmeyer, 1998: 963 [catalog]; Garavello \& Britski, 2003: 73 [catalog].

Anostomus (Laemolyta) garmani: Géry, 1977: 179 [identification key, distribution].

Anostomus garmani: Vari \& Howe, 1991:5. [Paratype, catalog]; Eschmeyer, 1998: 631 [catalog].
Material examined: 50 specimens (39.8-214.6 mm SL). Brazil. Amazonas: Silva, lago Saracá (Lake Saracá at Silves), 0253'S, $58^{\circ} 21^{\prime}$ W, December 1865, Thayer S. V. R, MCZ 19370, holotype, $160.6 \mathrm{~mm}$ SL. Rio Hyutahy, rio Jutahy [rio Jutaí, tributary of rio Solimões), $02^{\circ} 43^{\prime}$ S, $66^{\circ} 57^{\prime} \mathrm{W}$, September 1865 , W. James, S.V. R. Thayer \& "Talismã", MCZ 19346, 7 out of 14 paratypes, 78.4$95.0 \mathrm{~mm}$ SL. Rio Içá, rio Putomajo [rio Içá, tributary of rio Solimões,

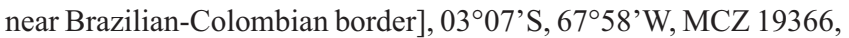
3 out of 5 paratypes, 63.6-72.9 mm SL. Rio Hyavary, rio Javary [rio Javarí, tributary of rio Solimões, at Peruvian Brazilian border], $04^{\circ} 21^{\prime} \mathrm{S}, 70^{\circ} 02^{\prime} \mathrm{W}, 19$ October 1865, Bourget, D, MCZ 32099, 1 out of 2 paratypes, $116.7 \mathrm{~mm}$ SL. Silva, lago Saracá [Lago Saracá at Silves], (0253'S, $58^{\circ} 21^{\prime}$ W), December 1865, Thayer, S.V. R MCZ 94491, 1 paratype, $163.7 \mathrm{~mm}$ SL. Lago do Castanho, INPA 10823, 1, 126.2 mm SL. Janauacá, rio Solimões, INPA 15210, 1, $75.3 \mathrm{~mm}$ SL. Janauacá, rio Solimões, INPA 10876, 1, 213 mm SL. Rio Tefé, Ressaca de Paula, Tefé, MZUSP 32402, 14, 159.9-214.6 mm SL. Igarapé Baré, lago Amaná, mouth of rio Japurá, MZUSP 36070, 1, $151.8 \mathrm{~mm}$ SL. Igarapé Urumutum, mouth of rio Japurá, MZUSP 36072, 1, 178.1 mm SL. Rio Tefé, lago Tefé, MZUSP 61643, 1, 195 mm SL. Rio Tefé, lago Mucura, MZUSP 61814, 1, 78.6 mm SL. Lago Manacapuru, rio Solimões, MZUSP 63614, 1, 188.3 mm SL. Barra do rio Negro, NMW 56988:2, 1, 164.7 mm SL. Pará: lago Maria Preta, rio Capim, MZUSP 63828, 1, $39.8 \mathrm{~mm}$ SL. Mato Grosso: rio Aripuanã, ilha do Castanhal, INPA 24727, 1, $168.8 \mathrm{~mm}$ SL. Rondônia: Forte Príncipe da Beira, rio Madeira, MZUSP 21381, 1, 50.4 mm SL.Goiás: rio Araguaia, Xambioá, INPA 1601, 1, 142.3 mm SL. Ecuador. Napo: río Yasuni, laguna Jatuncocha FMNH 102132, 1, $77.9 \mathrm{~mm}$ SL. Peru. Concordia: río Marañon, tributary of río Nacuary (open water), MHNG 2197.38, 1, $71.1 \mathrm{~mm} \mathrm{SL}, 59$ (type material of Laemolyta garmani macra). Departamento Loreto, Quebrada de río Yanayacu W of Miraflores (río Marañon), ANSP 165049, 1, 67.9 mm SL. Departamento Loreto, Provincia Maynas, Iquitos, Moronacocha, MZUSP 26333, 5, 44.5-82 mm SL. Loreto, río Nanay, about $20 \mathrm{~km}$ above mouth, main channel, lateral channels and lateral ponds, USNM 383198, 1, $70.2 \mathrm{~mm}$ SL.

Diagnosis. Laemolyta garmani is the only species in the genus with 4 longitudinal scale rows above the lateral line. Its color pattern is very similar to that of $L$. taeniata and $L$. orinocensis, but the dark longitudinal midlateral stripe and the narrow longitudinal light stripes above the lateral line are less conspicuous in L. garmani whereas L. orinocensis has more lateral line scales (40-44 vs. 47-52).

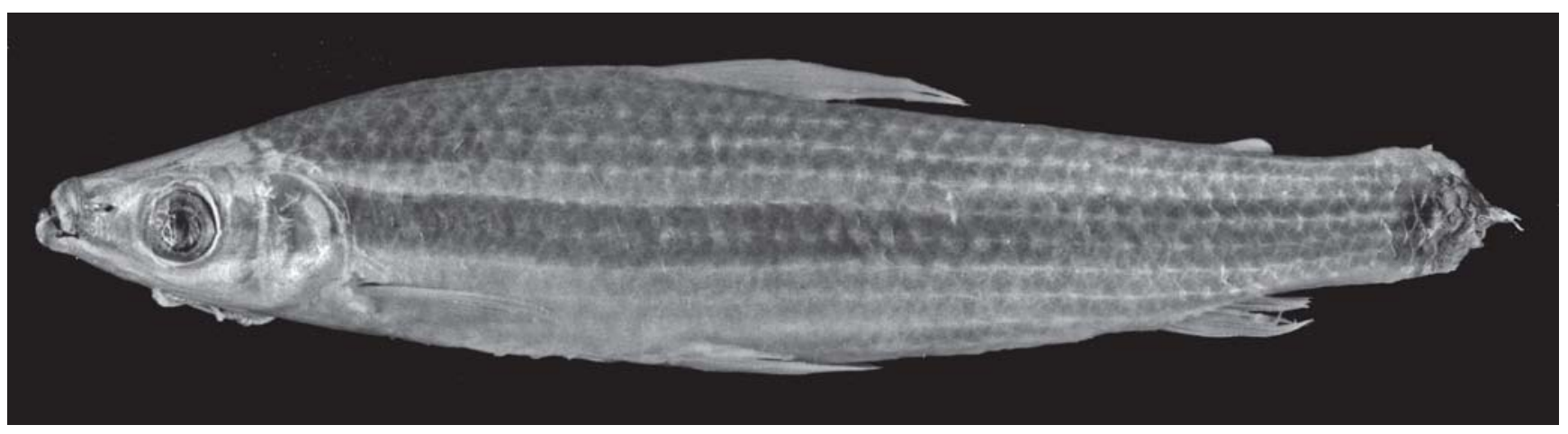

Fig. 12. Laemolyta garmani, holotype, MCZ 19370, 160.6 mm SL; Brazil, Amazonas, Silva, lago Saracá. Caudal fin entirely damaged and lacking in the holotype. 
Description. Morphometric and meristic data are presented in Table 3. Body moderately large ( $\mathrm{SL}=39.8-214.6 \mathrm{~mm})$. Dorsal profile of body straight, posterodorsally-aligned from tip of snout to end of supraoccipital spine, straight and rising from this point to dorsal-fin origin, straight and posteroventrally-aligned from that point to caudal peduncle. Ventral profile of body approximately straight and posteroventrally-aligned from tip of lower jaw to near isthmus, slightly convex from that point to anal-fin origin. Dorsal limb gill rakers on first gill arch 9-11, 12-14 on ventral limb.

Scales large, 40-44 (42*, usually 43, Table 2 ) perforated on all of lateral line. Longitudinal scale rows from lateral line to dorsal-fin origin 4; scales rows from lateral line to anal-fin origin 4. Predorsal scales 10-13 (10*, usually 11$)$, scales regularly arranged in most specimens. Scales rows around caudal peduncle $15-16\left(15^{*}\right.$, usually 16$)$.

Dorsal-fin rays i or ii,10-12 (10*, usually 11); distal margin of fin slightly rounded. Anal fin short and slightly falcate, with i-ii, 8-9 (8*, usually 8 ) rays. Pectoral fin rays i, 10-14 (12*, usually 14). Pelvic fin rays i,8; distal margin of fin truncate. Vertebrae $40(\mathrm{~N}=3)$.

Color in alcohol. Upper part of body dark with dark coloration extending ventrally to about 1.5 longitudinal scale rows above lateral line. Conspicuous dark, midlateral, longitudinal stripe covering 1 to 1.5 longitudinal scale rows and extending from tip of snout to rear of caudal peduncle; stripe sometimes wider in opercular region and narrower in snout region and near to caudal peduncle. Scales above lateral line with central posterior region lighter and forming narrow light stripes or linear pattern of light dots along body.

Dorsal, pectoral, pelvic and caudal fins hyaline. Anal and adipose fins with scattered dark chromatophores.

Distribution. Amazon basin (Fig. 13).

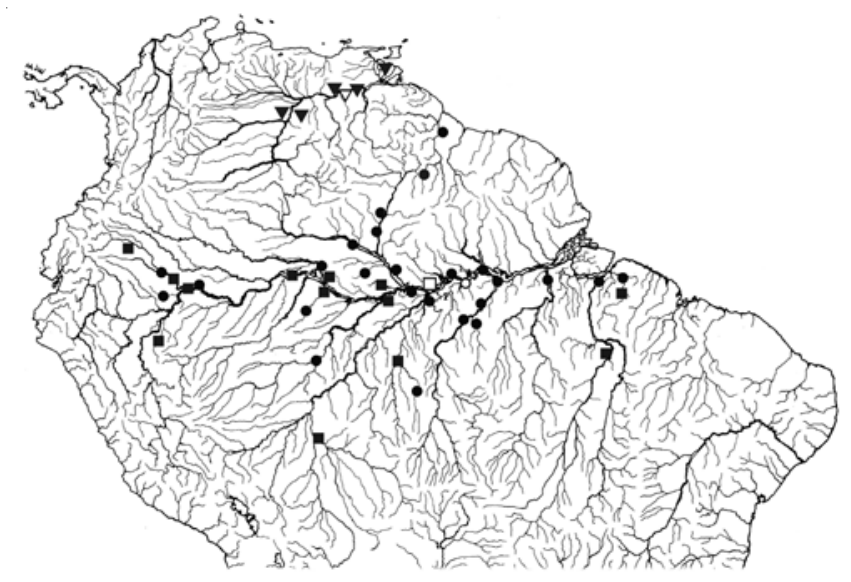

Fig. 13. Geographic distribution of Laemolyta proxima (black dots; open circle = type-locality), Laemolyta garmani (black squares; open squares = type-locality), and Laemolyta orinocensis (black triangles; open triangle = type-locality). Some symbols might correspond to more than one locality.

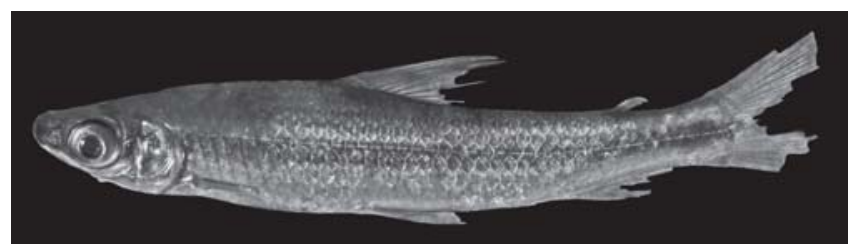

Fig. 14. Laemolyta garmani named "Laemolyta garmani macra”, MHNG 2197.38, 71.1 mm SL; Peru, río Marañon, Concordia, tributary of río Nucuray. Caudal fin damaged.

Remarks. Borodin (1931) described Laemolyta garmani and considered it to be very similar to L. taeniata, but distinguished his species by having larger and fewer scales and by the presence of a darker longitudinal stripe, fins, and scales. He also mentioned that the longitudinal dark stripe extends onto the middle caudal-fin rays and is clearly visible in preserved specimens even after 64 years. These characteristics and the presence of dark chromatophores on the fins and scales although less evident, are also present in L. taeniata, and, thus, are not useful to distinguish the two species. The two nominal species, however, can be separated primarily on the basis of scale size and consequently scale counts.

Laemolyta garmani was originally considered by Géry (1964) to be a subspecies of L. taeniata but later that author (1974) raised it to the species level and at the same time described a new subspecies, Laemolyta garmani macra based on a small sample of young specimens that had a shallower body. The holotype of this subspecies was not examined but M. Toledo-Piza (DZ-IBUSP) made counts and measurements on the specimen and a photo (Fig. 14) was provided by $\mathrm{C}$. Weber (MNHG).

Figure 15 demonstrates that the body depth of the holotype of Laemolyta garmani macra does not differ significantly when compared to all the examined specimens of $L$. garmani. Although body depth varies to a certain extent among the specimens, there is no statistical difference to justify recognition of a subspecies.

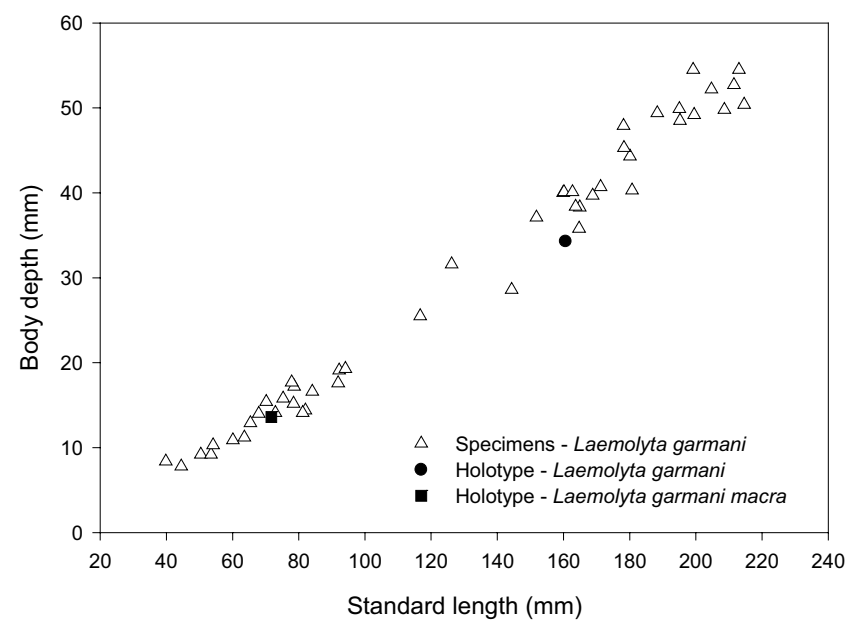

Fig. 15. Scatter plot of body depth on standard length for specimens and holotypes Laemolyta garmani. 
Table 2. Frequency distribution of lateral line scales in Laemolyta.

\begin{tabular}{llllllllllllllllllllll}
\hline Lateral line scales & 40 & 41 & 42 & 43 & 44 & 45 & 46 & 47 & 48 & 49 & 50 & 51 & 52 & 53 & 54 & 55 & 56 & 57 & 58 & mean & $\mathrm{N}$ \\
\hline Laemolyta fernandezi & & & & & & & & & & 3 & 5 & 12 & 10 & 22 & 15 & 15 & 6 & 3 & 1 & 53.2 & 92 \\
Laemolyta garmani & 1 & 2 & 9 & 27 & 10 & & & & & & & & & & & & & & & 42.9 & 49 \\
Laemolyta orinocensis & & & & & & & & 1 & 2 & 3 & 1 & 1 & 1 & & & & & & & 49.2 & 9 \\
Laemolyta proxima & & & & 1 & 35 & 111 & 87 & 9 & & & & & & & & & & & & 45.3 & 243 \\
Laemolyta taeniata & & & 7 & 32 & 90 & 74 & 3 & & & & & & & & & & & & & 44.2 & 206 \\
\hline
\end{tabular}

In his original description of Laemolyta taeniata, Kner (1859) mentioned that two specimens from Barra do rio Negro had thinner bodies, and some other divergent unspecified characters relative to the other examined specimens. One of these specimens, considered to be the syntype of L. taeniata (NMW 56988:2) was examined and proved to be identical to all the other specimens of L. garmani studied. This species was collected in sympatry with Laemolyta proxima and $L$. taeniata in Peru.

\section{Laemolyta orinocensis (Steindachner, 1879)}

Fig. 16

Anostomus orinocensis Steindachner, 1879: 154, plate II, fig. 7 and 7a. [original description, type-locality: río Orinoco]; Garman, 1890: 20, 21 [correction of meristic data]; Eigenmann, 1910: 425 [listed]; Eschmeyer, 1998: 1250 [catalog].

Laemolyta orinocensis: Eigenmann \& Eigenmann, 1891: 50

[listed]; Myers, 1950: 197 [diagnosis, type-locality]; Géry, 1964: 466 [identification key]; Géry, 1974: 159 [identification key]; Taphorn et al., 1997:55-100 [catalog]; Garavello \& Britski, 2003: 73 [catalog]; Lasso et al., 2004:105-195 [list of species and distribution].

Anostomus (Schizodontopsis) orinocensis: Borodin, 1931: 48 [listed].

Anostomus (Laemolyta) orinocensis: Géry, 1977: 182 [identification key, distribution].

Laemolyta proxima non (Garman, 1890): Lasso, 1992: 15, fig. 4, 22 [in part, only lot MHNLS 5512, specimen $90.3 \mathrm{~mm} \mathrm{SL].}$

Material examined. Nine specimens (76.7-166.7 mm SL). Venezuela. Ciudad Bolivar, Orinoco, NMW 62820, 1 lectotype (by present designation), $166.7 \mathrm{~mm} \mathrm{SL}$; Ciudad Bolivar, Orinoco, NMW 62595, 1 paralectotype, $149.1 \mathrm{~mm}$ SL. Anzoategui, Independencia, laguna Terecaya, to the side of río Orinoco, near
Ciudad Bolivar, MZUSP 62443, 2, 130.7-134.5 mm SL. Apure, laguna $2 \mathrm{~km}$ SE of caño la Pica, MHNLS 4231, 1 of 7, $133.5 \mathrm{~mm}$ SL. Río Suapure, Rabo de Cochino, Pijiguaos, MHNLS 5512, 1 of 3, $90.3 \mathrm{~mm}$ SL. Anzoategui, paso de río Mamo, $2 \mathrm{~km}$ from Juajullal, via Mamo, Soledad, MHNLS 8250, 2 of 3, 89.5-94.7 mm SL. Delta Amacuro, caños Macareo y Mariusa, delta río Orinoco, caño el Tambor (tributary of caño Macareo), MHNLS 14019, 1 of 2, 76.7 mm SL.

Diagnosis. Laemolyta orinocensis can be distinguished from $L$. garmani, L. taeniata and L. proxima in having more scales along the lateral line (47-52, usually 49 vs. 40-47), from L. garmani and L. taeniata in having more longitudinal rows of scales from the lateral line to the dorsal-fin origin (7-8 vs. 4-5) and from the lateral line to the anal-fin origin (6 vs. 4-5) and also by lacking longitudinal light stripes above the lateral line (vs. having such stripes). Laemolyta orinocensis differs from L. fernandezi by

Table 3. Morphometrics of Laemolyta garmani.

\begin{tabular}{lccccc}
\hline Character & Holotype & $\mathrm{N}$ & Range & Mean & SD \\
\hline Standard length (mm) & 73.1 & 91 & $63.6-212.9$ & 134.2 & - \\
& Percents of standard length & & \\
Preanal distance & 77.6 & 91 & $77.8-85.2$ & 80.4 & 1.00 \\
Preventral distance & 46.4 & 91 & $45.2-51.6$ & 48.3 & 1.23 \\
Prepectoral distance & 25.4 & 91 & $20.6-26.7$ & 23.4 & 1.24 \\
Predorsal distance & 45.1 & 91 & $42.8-46.7$ & 44.6 & 1.83 \\
Body depth & 23.7 & 91 & $22.9-31.6$ & 27.2 & 2.00 \\
Caudal-peduncle depth & 9.30 & 91 & $9.10-11.0$ & 10.2 & 0.41 \\
Caudal-peduncle length & 14.5 & 91 & $9.70-14.5$ & 11.8 & 0.85 \\
Dorsal-fin length & 26.8 & 91 & $22.5-29.2$ & 25.9 & 1.40 \\
Ventral-fin length & 18.6 & 91 & $14.7-19.3$ & 17.1 & 0.93 \\
Pectoral-fin length & 17.6 & 91 & $15.6-18.9$ & 17.5 & 0.81 \\
Anal-fin length & 13.1 & 91 & $9.50-14.3$ & 12.6 & 0.81 \\
Head length & 24.1 & 91 & $19.8-25.0$ & 23.0 & 0.88 \\
Dorsal-fin base length & 14.9 & 91 & $12.5-31.0$ & 14.7 & 1.80 \\
Anal-fin base length & 10.5 & 91 & $7.30-10.6$ & 8.90 & 0.63 \\
& Percents of head length & & \\
Eye diameter & 37.5 & 91 & $26.1-39.0$ & 32.0 & 2.30 \\
Antorbital length & 34.1 & 91 & $32.6-42.2$ & 37.7 & 2.03 \\
Interorbital distance & 39.8 & 91 & $36.8-49.8$ & 43.3 & 2.65 \\
Body width opercle & 49.4 & 91 & $50.0-63.9$ & 56.5 & 3.15 \\
\hline
\end{tabular}

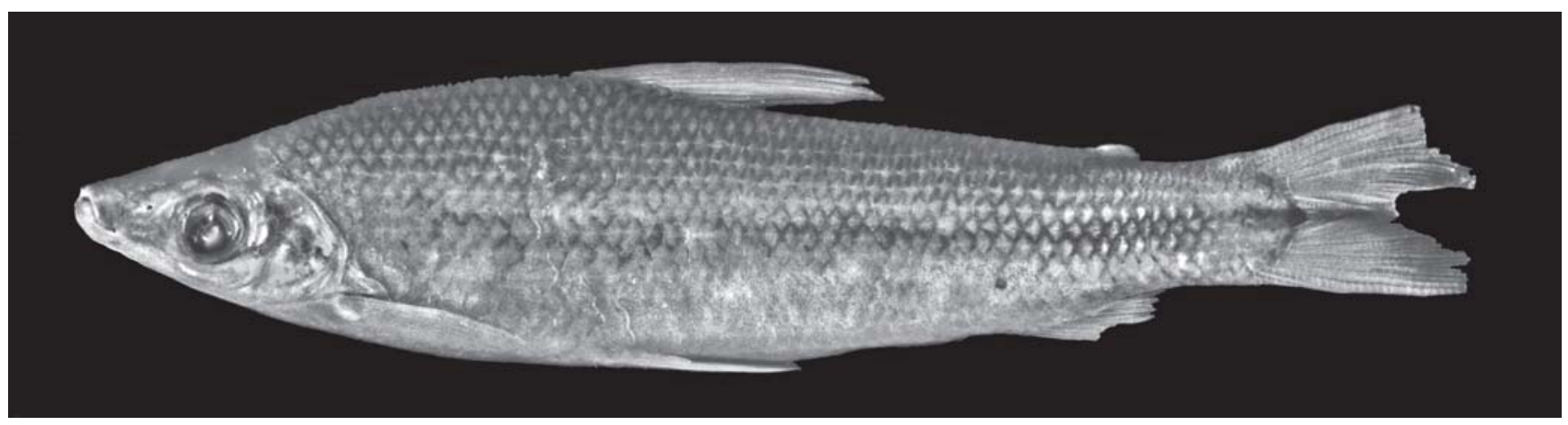

Fig. 16. Laemolyta orinocensis, NMW 62820: 1, lectotype, 166.7 mm SL; Venezuela, Ciudad Bolivar, río Orinoco. 


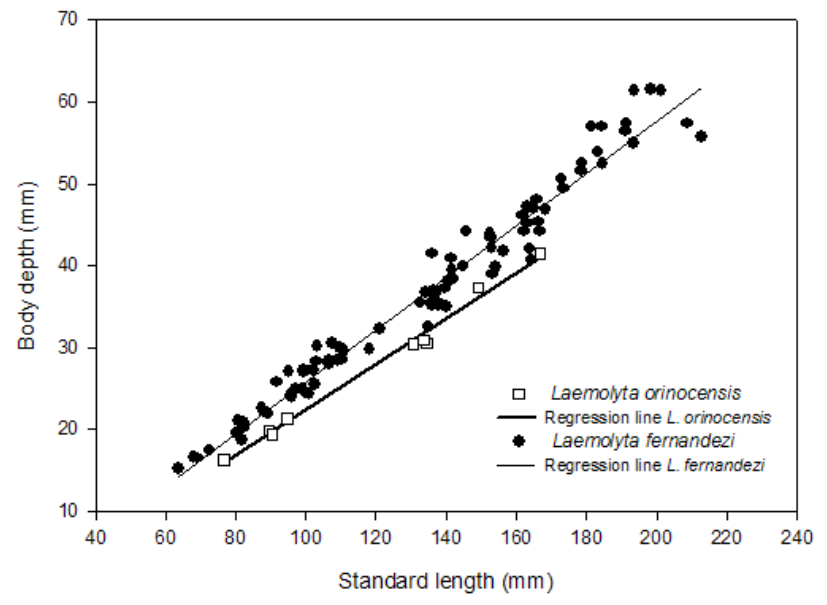

Fig. 17. Regression lines of body depth on standard length for specimens of Laemolyta orinocensis and L. fernandezi.

the conspicuous midlateral longitudinal dark stripe and the very inconspicuous transverse dark bars on the body $v s$. an inconspicuous median longitudinal dark stripe and four transversal dark bars or blotches on the body in L. fernandezi. It can also be further distinguished from L. fernandezi in having a shallower body (21.3-25.1\% vs. 22.9-31.6\%, Fig. 17).

Description. Meristic and morphometric data presented in Table 4. Body moderately large (SL=76.7-166.7 mm). Dorsal profile of body straight or slightly concave from tip of snout to end of supraoccipital spine, slightly convex from that point to dorsal-fin origin, straight and posteroventrally-inclined or slightly convex from base of posterior-most dorsal-fin ray and straight and posteroventrally-inclined or slightly convex from that point to caudal peduncle. Ventral profile of body slightly convex from tip of lower jaw to near isthmus, slightly convex from that point to anal-fin origin and slightly concave at insertion of pelvic fins.

Perforated scales on lateral line 47-52 (47*, usually 49, Table 2). Longitudinal scale rows from lateral line to dorsalfin origin $7-8\left(7^{*}\right.$, usually 7$)$; scales rows from lateral line to anal-fin origin $6\left(6^{*}\right)$. Predorsal scales irregularly arranged. Scales rows around caudal peduncle 16-20 (19*, usually 19).

Dorsal-fin rays ii, 11; distal margin of fin slightly rounded.
Table 4. Morphometrics of Laemolyta orinocensis.

\begin{tabular}{lccccc}
\hline Character & Lectotype & $\mathrm{N}$ & Range & Mean & SD \\
\hline Standard length (mm) & \multicolumn{1}{c}{166.7} & 8 & $76.7-149.1$ & 112.4 & - \\
& Percents of standard length & & \\
Preanal distance & 80.3 & 8 & $77.1-79.5$ & 78.5 & 0.82 \\
Preventral distance & 46.9 & 8 & $45.3-47.4$ & 46.0 & 1.08 \\
Prepectoral distance & 22.2 & 8 & $22.7-24.8$ & 23.8 & 0.90 \\
Predorsal distance & 44.4 & 8 & $41.9-44.1$ & 43.1 & 0.75 \\
Body depth & 24.9 & 8 & $21.3-25.1$ & 22.7 & 1.43 \\
Caudal-peduncle depth & 10.3 & 8 & $8.60-10.7$ & 9.70 & 0.45 \\
Caudal-peduncle length & 11.5 & 8 & $11.9-13.3$ & 12.6 & 1.08 \\
Dorsal-fin length & 24.8 & 8 & $23.3-27.8$ & 25.5 & 0.84 \\
Ventral-fin length & 17.2 & 8 & $16.6-18.7$ & 17.3 & 0.73 \\
Pectoral-fin length & 17.3 & 8 & $15.6-19.2$ & 17.7 & 0.44 \\
Anal-fin length & - & 8 & $11.5-13.2$ & 12.4 & 0.40 \\
Head length & 21.5 & 8 & $22.2-25.4$ & 23.3 & 0.53 \\
Dorsal-fin base length & 14.1 & 8 & $14.4-15.5$ & 14.9 & 0.36 \\
Anal-fin base length & 8.80 & 8 & $9.00-10.7$ & 9.60 & 0.52 \\
& Percents of head length & & \\
Eye diameter & 30.5 & 8 & $30.3-35.0$ & 33.3 & 2.23 \\
Antorbital length & 34.3 & 8 & $33.7-38.0$ & 35.8 & 1.90 \\
Interorbital distance & 47.3 & 8 & $37.9-44.8$ & 41.4 & 2.59 \\
Body width opercle & 56.3 & 8 & $51.3-56.9$ & 54.5 & 2.99 \\
\hline
\end{tabular}

Anal fin short, slightly falcate, with ii, 8 rays. Pectoral-fin rays i,11-14 (14*, usually 14). Pelvic-fin rays i,8; distal margin of fin truncate. Vertebrae 41-43 (43*, usually 42, $N=7$ ).

Color in alcohol. Large adult specimens with dorsal part of body usually dark, extending ventrally to 1 or 2 longitudinal scale rows above lateral line. Conspicuous dark midlateral longitudinal stripe covering 1.5 to 2 longitudinal scale rows extending from tip of snout to rear of caudal peduncle. Ventral part of body lighter from lower limit of longitudinal dark stripe to midventral line. Some specimens with very inconspicuous dark blotch present posterior to opercular margin and another one under dorsal-fin base.

Dorsal, pectoral, and pelvic fins hyaline. Scattered dark chromatophores on anal and caudal fins and along dorsal and ventral edges and median rays of caudal fin.

Young specimens (Fig. 18) with dark, midlateral, longitudinal stripe more conspicuous and narrower at opercle and caudal peduncle. Some specimens with narrow, transverse, dark bars on dorsal part of body and with anal fin dark.

Distribution. Rio Orinoco basin (Fig. 13).

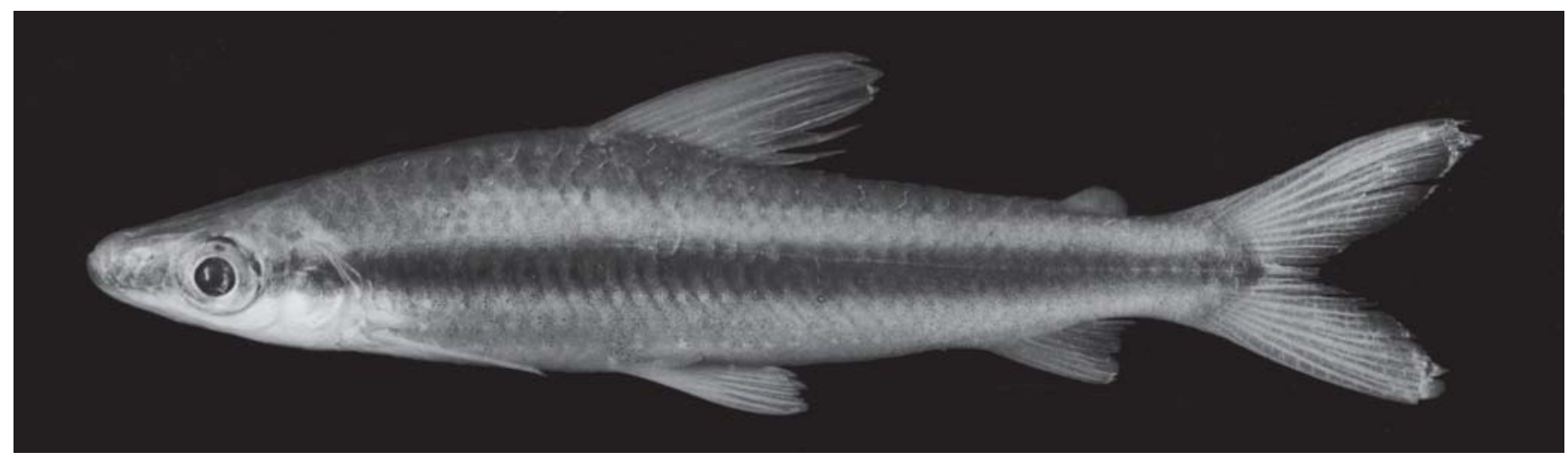

Fig. 18. Young of Laemolyta orinocensis, MHNLS 4231, 133.5 mm SL; Venezuela, Apure, Laguna, 2 km southeast of caño la Pica. 


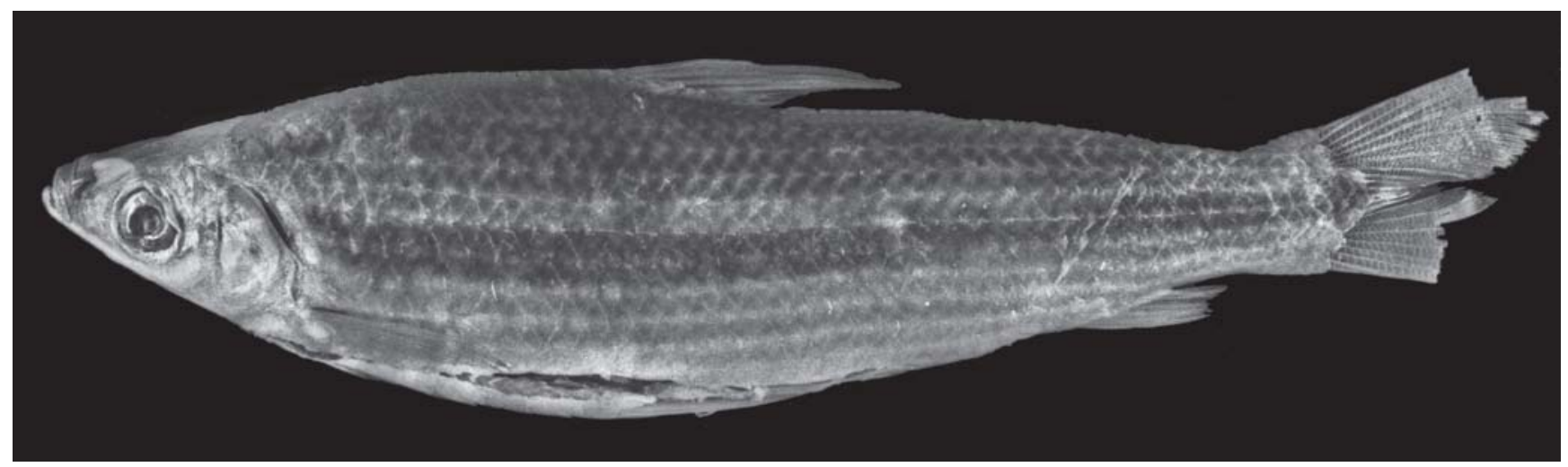

Fig. 19. Laemolyta proxima, MCZ 19331, lectotype, 165.3 mm SL; Brazil, Amazonas, rio Amazonas, Vila Bela, Parintins.

Remarks. Laemolyta orinocensis was considered by Steindachner (1879) to be very similar to L. taeniata (Kner), but to differ from it in scales counts. In the original description of L. orinocensis, Steindachner (1879) referred to the presence of 3.5 scales between the lateral line and the ventral margin of the body, but Garman (1890) observed that this count is probably incorrect since six scales can be easily counted below the lateral line in the figure of the species in Steindachner's paper. Laemolyta orinocensis and L. taeniata are very similar in having the dark, longitudinal midlateral stripe on body more evident in young specimens; however, in L. orinocensis the dorsal and ventral margins of the stripe are not absolutely straight. In the syntype specimens (NMW 62820:1 and 62595:1) the longitudinal dark stripe is no longer apparent. In these specimens, however, a vestigial longitudinal dark stripe is still visible, but most of the stripe is silvery due to the presence of guanine on the scales. The silvery color on the centers of the scales above the lateral line form a reticulate pattern. In the original description, Steindachner (1879) designated two syntypes (NMW 62820:1 and 62595:1). The one specimen in NMW 62820:1 is herein designated as the lectotype.

Notwithstanding the similarity of color patterns between young specimens of L. orinocensis and L. fernandezi, the dark longitudinal stripe on the midlateral portion of the body is more conspicuous in L. orinocensis. Laemolyta orinocensis furthermore lacks the dark peduncular spot present in $L$. fernandezi

\section{Laemolyta proxima (Garman, 1890)} Fig. 19

Anostomus (Schizodontopsis) proximus Garman, 1890 : 19 [original description, type locality: Villa Bella and Ueranduba]; Borodin, 1931:47 [diagnosis, MCZ material listed]; Eschmeyer, 1998: 1386 [catalog].

Laemolyta proximus: Eigenmann \& Eigenmann, 1891:50 [listed]. Anostomus proximus: Eigenmann, 1910: 425 [listed].

Laemolyta proxima: Myers, 1950: 197 [diagnosis, typelocality]; Fowler, 1950: 209 [synonymy list, distribution]; Géry, 1964: 466 [identification key], 1974:155-157, 159 [diagnosis, description, identification key]; Garavello \& Britski, 2003: 73 [catalog].
Anostomus (Laemolyta) proximus: Géry, 1977: 182 [synonymy, identification key, distribution].

Anostomus (Schizodontopsis) varius Garman, 1890: 19, 20 [original description, type-locality: Gurupa, José Fernandes, Lake Hyanuary, Manaos (Manaus), Obydos (Óbidos), Porto do Moz, rio Negro]; Ulrey, 1895: 261 [morphological data, color pattern]; Borodin, 1931: 46-47 (diagnosis, MCZ material listed]; Eschmeyer, 1998: 1745 [catalog].

Anostomus varians [error]: Eigenmann \& Eigenmann, 1891: 425 [listed].

Laemolyta varia: Myers, 1950: 197 [diagnosis, type-locality]; Fowler, 1950: 209 [synonymy list, distribution]; Géry, 1964: 466 (identification key]; 1974: 155-157, 159 [diagnosis, description, identification key]; Santos, 1982: 713-739 [ecological data]; Santos \& Jegú, 1996: 161, fig. 11, p. 179 [INPA's material listed, rio Uatumã (Amazon basin)]; Garavello \& Britski, 2003: 73 [catalog].

Anostomus varius: Vari \& Howe, 1991: 5 [type catalog].

Anostomus (Schizodontopsis) varius nitens Garman, 1890: 20 [original description, type-locality: Iça]; Borodin, 1931:47 [diagnosis]; Eschmeyer, 1998: 1190 [catalog].

Laemolyta varius nitens: Eigenmann \& Eigenmann, 1891: 50 [listed].

Anostomus varians [error] nitens: Eigenmann, 1910: 425 [listed].

Anostomus (Schizodontopsis) nitens: Borodin, 1931: 46-47 [diagnosis, material of MCZ listed)

Laemolyta nitens: Myers, 1950: 197 [diagnosis, type-locality]; Fowler, 1950: 209 [synonymy list, distribution]; Géry, 1964: 466 [identification key]; 1974:155-157, 159 [diagnosis, description, identification key]; Garavello \& Britski, 2003: 73 [catalog].

Anostomus (Laemolyta) nitens: Géry, 1977: 182 [identification key, distribution].

Anostomus nitens: Vari \& Howe, 1991:5 [type catalog].

Material examined. 244 specimens (48.1-249.9 mm SL). Brazil. Amazonas: Villa Bella (rio Amazonas at Parintins and environs), 27 August 1865, L. Agassiz, MCZ 19331, 1 lectotype (designated herein), 165.3 mm SL. Lago José Fernandes (location unknown, presumably near Manaus), November 1865, Maj. J. M. S., MCZ 
19378, 5 paralectotypes, 75.9-113.1 mm SL. Rio Negro at Manaus, 1863, J. C. Fletcher, MCZ 809, 1 paralectotype, 160.7 mm SL. Lago Hyanuary (Paraná do Janauari), 27 October 1865, L. Agassiz, MCZ 19335, 4 paralectotypes, 98.6-188.1 mm SL. Içá, November, 1865, USNM 120242, 3 paralectotypes, 82.9-92.5 mm SL. José Fernandes, 1867, USNM 120398, 1 paralectotype. Mouth of rio Ituxi, MZUSP 21487, 2, 168.7 and $174 \mathrm{~mm}$ SL. Lagoa Central, left bank of rio Negro, between rivers Camaraú and Apaú, MZUSP 21062, 3 of 4, 81.4-91.4 mm SL. Lago Janauacá, MZUSP 27898, 1, $80.0 \mathrm{~mm}$ SL. Lago Puraquequara, rio Amazonas, MZUSP 53640, 4, 65.6-83.4 mm SL. Lago Janauarí, MZUSP 62434, 3, 76-83.4 mm SL. Lago Manacapuru, MZUSP 5886, 1 of 2, 224.5 mm SL. Lago Berurí, rio Purus, MZUSP 6003, 2, 170.7 and $178.8 \mathrm{~mm}$ SL. Rio Negro near Manaus, MZUSP 6703, 1, $86.1 \mathrm{~mm}$ SL. Rio Madeira, $25 \mathrm{~km}$ below Nova Olinda, MZUSP 6964, 1, $95.1 \mathrm{~mm}$ SL. Rio Canumá, MZUSP 7058, 2, 170.8 and 188.9 mm SL. Paraná de Urucará, Urucará, MZUSP 7517, 3, 95.6-103.7 mm SL. Mouth of Lake José-Açu, Parintins, MZUSP 7643, 2, 99.2-119.9 mm SL. Lago Castro, mouth of rio Purus, MZUSP 20907, 1, 106.9 mm SL. Rio Negro, Cantagalo, MZUSP 43293, 1, 228 mm SL. Lago Janauacá, right bank of rio Solimões, MZUSP 21557, 1, $200.8 \mathrm{~mm}$ SL. Lago Janauacá and surroundings, rio Solimões, MZUSP 21693, 3, 175.5$239.6 \mathrm{~mm}$ SL. Costa do Japão, lower rio Japurá, Tefé, MZUSP 27381, 1, 101.8 mm SL, MZUSP 27382, 1, 92 mm SL. Rio Tefé, Mucurá, MZUSP 29186, 6, 72.2-97.3 mm SL, MZUSP 60185, 4 of 7, 188.5-214.4 mm SL. Rio Negro, Anavilhanas, MZUSP 29191, 2, 97.9-100.7 mm SL, MZUSP 32414, 1, 169.5 mm SL, MZUSP 32415, 3, 194.9-226.7 mm SL, MZUSP 60176, 1, 172.9 mm SL, MZUSP 60185, 4 of 7, 188.5-214.4 mm SL, MZUSP 60177, 1, $159.3 \mathrm{~mm}$ SL. Rio Tefé, Aranatuba, MZUSP 29187, 1 of 3, $97 \mathrm{~mm}$ SL. Rio Tefé, beach at Vista Escura, MZUSP 31426, 1, $178.4 \mathrm{~mm}$ SL, MZUSP 32403, 4 of 14, 169.8-249.9 mm SL Rio Tefé, Mastro, Ressaca, MZUSP 32399, 1, $208.3 \mathrm{~mm}$ SL. Rio Tefé, beach at Jurupari, MZUSP 32400, 5, 212.6-229.5 mm SL, MZUSP 61458, 5, 201.2-230.7. Lake at Tefé, MZUSP 32401, 8 of 17, 201.3-239.2 mm SL. Rio Tefé, Mastro, Capim, MZUSP 60171, 2, 214.6-224.7. Tefé, beach at Jurupari, MZUSP 60173, 1, 212.5 mm SL. Rio Tefé, Supiã-Pucu, MZUSP 60174, 3, 205.7-231.7 mm SL. Rio Tefé, Ressaca de Paula, MZUSP 60179, 11 of 23, 162.5-225.6 mm SL. Rio Negro, junction with Ararirá, MZUSP 60188, 1, 218 mm SL, MZUSP 60189, 5, 159.1-238.4 mm SL. Pará: Gurupá (rio Amazonas delta at Gurupá), 22 August 1865, L. Agassiz et al., MCZ 19340, 3 paralectotypes, $111.5-126.7 \mathrm{~mm}$ SL. Porto Moz, rio Xingu at Porto do Moz, 23 August 1865, L. Agassiz et al., MCZ 19341, 1 paralectotype, $175.9 \mathrm{~mm}$ SL. Rio Amazonas at Óbidos, November 1865, Bento, MCZ 19348, 2 paralectotypes, 87.8-103.8 mm SL. Óbidos (rio Amazonas at Óbidos), December 1865, James, W. \& W. Hunnewell, MCZ 19532, 1 paralectotype, 58.1 mm SL. Rio Tapajós, Pimentel, below mouth of rio Jamanxim, INPA 6906, 3, 54.0-65.6 $\mathrm{mm}$ SL. Rio Trombetas, lago Jacaré, Expedição do Departamento de Zoologia and Museu Goeldi, MZUSP 64066, 4, 117.8-132.1 mm SL. Lago Bernardino, near Badajós, rio Capim, MZUSP 6874, 1 of 2, $101.1 \mathrm{~mm}$ SL. Paraná Samuuma, mouth of rio Tocantins, MZUSP 21249, 2, 197-200.0 mm SL. Igarapé Açu, Aveiro, MZUSP 21360 , 1, 125.3 mm SL. Rio Tapajós, São Luís, MZUSP 21388, 1 of 2, 191.3 mm SL. Rio Tapajós, Barreirinha, MZUSP 21411, 1, 178.3 mm SL. Rio Tapajós, Maloquinha, MZUSP 21400, 2, 173.3 and $186.1 \mathrm{~mm}$ SL. Rio Tapajós, lake in front of Monte Cristo, MZUSP 21414, 1, 148.4 mm SL. Igapó do lago Farias, rio Trombetas, Trombetas Biological Reserve, MZUSP 15788, 1, 202.3 mm SL, MZUSP 1596061, $1200.1 \mathrm{~mm}$ SL. Rio Xingu, Belo Monte, river channel, MZUSP 60182, 5 of 19, 179.5-194.8 mm SL, MZUSP 61640, 1 of 2, 192.1 mm SL. Rio Tapajós, between Itaituba and São Luís, MZUSP 61640, 1 of 2, $192.1 \mathrm{~mm}$ SL. Rio Trombetas, $20 \mathrm{~km}$ above mouth, MZUSP 61950, 1, 145.5 mm SL. Roraima: rio Branco, INPA 14046, 5, 74.797.2 mm SL. Rio Branco, Marará, Paraná-Fechada, MZUSP 60183, 2, 205.2-210.6 mm SL. Rio Branco between mouth and rio Xeriuni, MZUSP 61443, 1, 197.4 mm SL. Rio Branco, beach and Paraná at Marará, MZUSP 61642, 5, 149.6-191.7 mm SL. Bolivia, Beni: río Baures at mouth on right bank $6 \mathrm{~km} \mathrm{SW}$ of Costa Marques, AMNH 39987, 6, 48.1-143.9 mm SL. Río Itenez, $1 \mathrm{~km}$ downstream (W) of Costa Marques, Mamoré-Madeira-Amazon drainage, UMMZ 204904, 3, 69.9-187.7 mm SL. Guiana. Essequibo River, Rockstone, ANSP 137804, 1, 114.8 mm SL. Peru. Loreto: río Nanay, well above Moronacocha, vicinity of Iquitos, ANSP 137804, 1, $114.8 \mathrm{~mm}$ SL. Itaya, Ancieta, UMMZ 216875, 1, 96.7 mm SL. Shansho caño, drainage of Ampiyacu, USNM 175839, 1, 144.9 mm SL. Río Itaya, main channel and portions below caños, 5 to $20 \mathrm{~km}$ above Belen, Iquitos, USNM 280741, 1, 74 mm SL. Río Nanay, approximately $20 \mathrm{~km}$ above mouth, main channel, lateral channels and ponds, USNM 280712,3 of $4,76.8-81.7 \mathrm{~mm}$ SL.

Diagnosis. Laemolyta proxima differs from L. garmani and L. taeniata in having more longitudinal rows of scales from the lateral line to the dorsal-fin origin (6-8 vs. 4-5) and also from $L$. garmani in having more longitudinal rows of scales from the lateral line to the anal-fin origin (5-6 vs. 4). Laemolyta proxima differs from $L$. orinocensis in having fewer scales along the lateral line (43-47, usually 45 vs. 47-52). Laemolyta proxima has fewer perforated scales along the lateral line than does L. fernandezi (43-47 vs. 49-58).

Description. Meristic and morphometric data presented in Table 5. Body moderately large ( $\mathrm{SL}=48.1-249.9 \mathrm{~mm} \mathrm{SL})$. Dorsal profile of body straight from tip of snout to end of supraoccipital spine, slightly convex from that point to origin of dorsal fin, straight and posteroventrally-inclined along dorsal-fin base and straight and posteroventrally-inclined or slightly convex from posterior margin of dorsal-fin base to caudal peduncle. Ventral profile of body almost straight from tip of lower jaw to region near isthmus, slightly convex from that point to origin of anal fin, and slightly concave at insertion of pelvic fins.

Gill rakers on dorsal limb of first branchial arch 9-12 and 10-14 on lower limb.

Perforated scales on lateral line 43-47 (46*, usually 45, Table 2). Longitudinal scale rows from lateral line to dorsalfin origin 6-8 (6*, usually 6$)$; scales rows from lateral line to anal fin origin 5-6 (5*, usually 5). Predorsal scales irregularly arranged. Scales rows around caudal peduncle $16\left(16^{*}\right)$.

Dorsal-fin rays ii-iii,10-12 (11*, usually 11); distal margin of fin convex. Anal fin short, slightly falcate, with i-ii, 8 rays. Pectoral fin rays i,11-16 (13*, usually 13$)$. Pelvic fin rays i,79 ( $8^{*}$, usually 8$)$; distal margin of fin truncate. Vertebrae $41-42$ (42*, usually $42, \mathrm{~N}=5)$.

Color in alcohol. Dorsal region of body of adult specimens (Fig. 20) generally dark, extending ventrally to within 1-1.5 longitudinal scale rows above lateral line. Sometimes inconspicuous dark midlateral longitudinal stripe, covering 1.5 to 2 


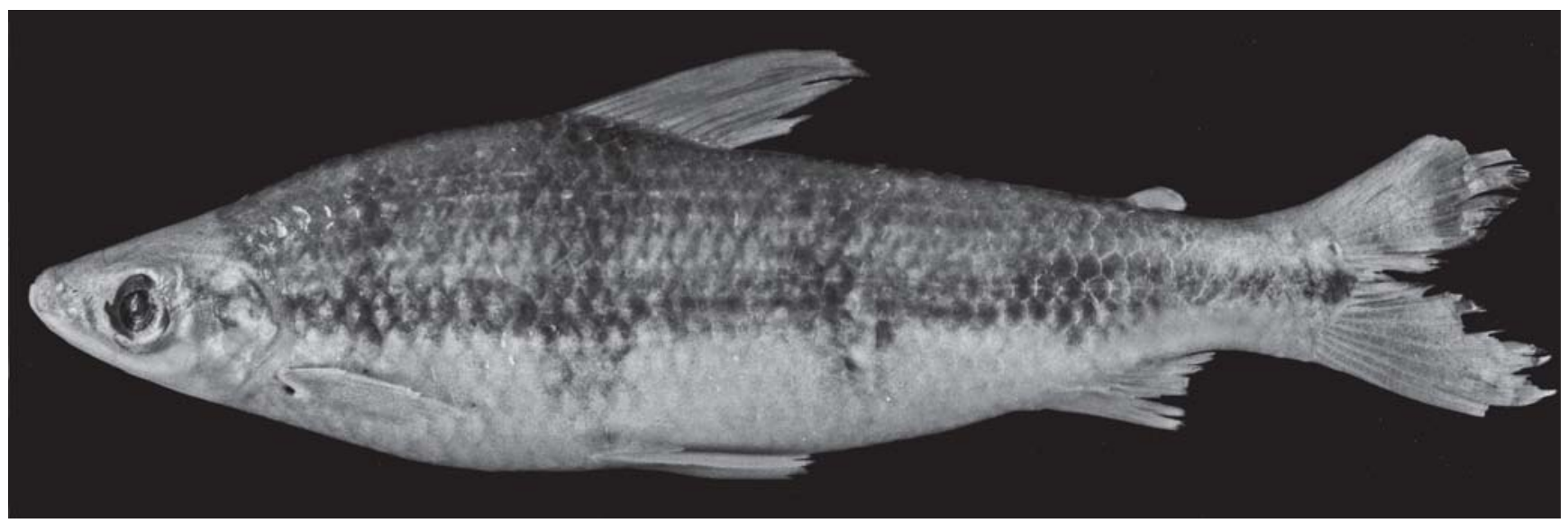

Fig. 20. Adult specimen of Laemolyta proxima, MZUSP 61642, 180.3 mm SL; Brazil, Roraima, rio Branco, Marará, Paraná-praia.

longitudinal scale rows extending from tip of snout to rear of caudal peduncle. Stripe ends in form of triangular or ovalshaped dark spot. Ventral part of body lighter from lower limit of longitudinal dark stripe to midlateral line. Four vertical dark bars sometimes crossing body, first located between opercle and dorsal fin nearer to opercle, second under dorsal fin, third between pelvic and anal fins, and fourth anterior to vertical through base of adipose fin. Young specimens with highly variable number of narrow, transverse, dark bars (up to 26) extending from dorsal margin of body to near lateral line. Dorsal, pectoral, pelvic and caudal fins hyaline. Anal and adipose fins with scattered dark chromatophores.

Several specimens from the rio Tapajós have the body coloration very light with the dorsum dark and the remaining parts of body almost entirely silvery. Santos (1982) examined young specimens (up to $70 \mathrm{~mm} \mathrm{SL}$ ) bearing 12 to 16 dark, vertical bars on the dorsal part of the body. According to author, specimens longer than $70 \mathrm{~mm}$ SL tend to loose most of these bars, with only those which form the four bars found in adult specimens retained. In the present study 14 to 26 dark, vertical bars were found in specimens smaller than $88 \mathrm{~mm} \mathrm{SL}$, with most having 14 to 16 bars. Other specimens did not show any dark bars or spots on the body probably due to the method of preservation. In some other individuals, only the longitudinal stripe (Fig. 21) and the transverse, dark bars or oval-shaped spots over the inconspicuous longitudinal stripe (Fig. 22) were visible.

Distribution. Amazon basin (Peru and Brazil) and Essequibo River in Guiana (Fig. 13).

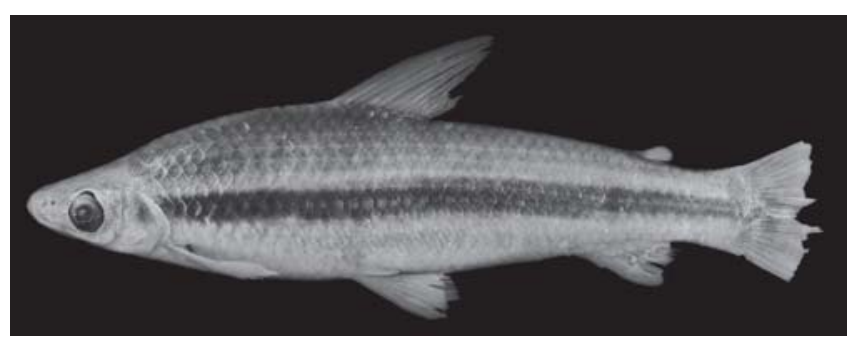

Fig. 21. Adult specimen of Laemolyta proxima, MZUSP 64066, 132.1 mm SL; Brazil, Pará, rio Trombetas, Lago Jacaré.
Remarks. Laemolyta proxima was described by Garman (1890) as Anostomus (Schizodontopsis) proximus together with A. (Schizodontopsis) varius and A. (Schizodontopsis) nitens. These three species were recognized as distinct by Borodin (1931) who, nonetheless, considered the first $A$. proximus and $A$. varius to be very similar on the basis of their body shape and color pattern, and with A. nitens very similar to $A$. varius but having the body more elongate and with an overall lighter coloration.

Géry (1974) considered these three species as part of a complex and divided that into two units: the proxima-varia group, which was characterized by the presence of a dark, midlateral longitudinal stripe and nitens, which had dark spots over an inconspicuous dark longitudinal stripe, a larger orbital diameter, and the body more elongate. In the same paper, Géry cast doubts on the recognition of two different species within the first group. The same author (1977) included Laemolyta as a subgenus of Anostomus, considered L. nitens to be a valid species and provided an identification key which suggested that Anostomus (Laemolyta) proximus is a synonym of Anostomus (Laemolyta) varius.

According to Garman (1890) Laemolyta proxima would be closely related to $L$. taeniata from which it could be distinguished in having smaller and consequently more numerous scales. Indeed some of the examined specimens of $L$. proxima species have a color pattern identical to that of $L$. taeniata, but the differences in scale counts make their identification possible.

Notwithstanding the differences in color pattern and number of scales between Laemolyta varia and L. proxima re-

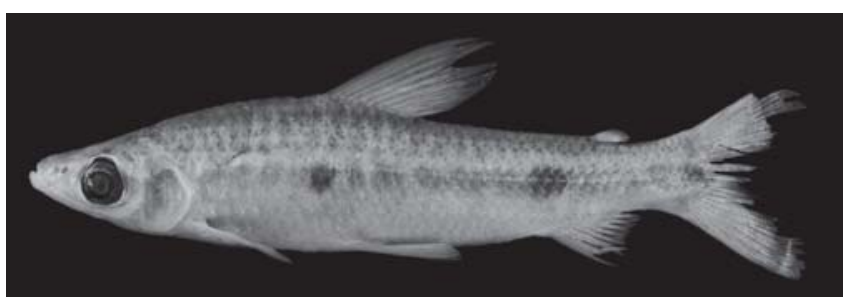

Fig. 22. Young specimen of Laemolyta proxima, MZUSP 27382, 92 mm SL; Brazil, Amazonas, Costa do Japão, Ressaca do Japão, lower rio Japurá. 
Table 5. Morphometrics of Laemolyta proxima.

\begin{tabular}{|c|c|c|c|c|c|}
\hline Character & Lectotype & $\mathrm{N}$ & Range & Mean & SD \\
\hline Standard length (mm) & 165.3 & 243 & $48.1-249.9$ & 154.8 & - \\
\hline \multicolumn{6}{|c|}{ Percents of standard length } \\
\hline Preanal distance & 80.9 & 243 & $75.9-82.5$ & 79.3 & 1.24 \\
\hline Preventral distance & 46.5 & 243 & $44.3-51.1$ & 47.2 & 1.18 \\
\hline Prepectoral distance & 21.8 & 243 & $20.1-28.7$ & 23.3 & 1.37 \\
\hline Predorsal distance & 45.3 & 243 & $41.3-47.6$ & 44.4 & 1.09 \\
\hline Body depth & 25.7 & 243 & $20.9-29.8$ & 25.5 & 1.70 \\
\hline Caudal-peduncle depth & 9.74 & 243 & $8.70-11.0$ & 9.8 & 0.43 \\
\hline Caudal-peduncle length & 11.5 & 243 & $10.0-14.0$ & 11.9 & 0.71 \\
\hline Dorsal-fin length & 24.4 & 243 & $20.4-31.4$ & 25.3 & 1.59 \\
\hline Ventral-fin length & 16.6 & 243 & $14.7-21.9$ & 17.1 & 1.12 \\
\hline $\mathrm{n}$ length & 6.6 & 243 & $13.8-24.5$ & 17.2 & 1.09 \\
\hline Ana & 11.7 & 243 & $9.50-15.0$ & 12.2 & 0.92 \\
\hline Head length & 22.0 & 243 & $19.9-27.4$ & 22.8 & 1.40 \\
\hline Dorsal-fin base length & 13.9 & 243 & $13.0-15.7$ & 14.3 & 0.51 \\
\hline Anal- & 9.10 & 243 & $7.70-10.8$ & 9.2 & 0.58 \\
\hline \multicolumn{6}{|c|}{ Percents of head length } \\
\hline Eye & 30.2 & 243 & $27.4-40.9$ & 31.7 & 2.40 \\
\hline Antor & 40.9 & 243 & 41.3 & 36.8 & 1.93 \\
\hline Inter & 43.7 & 243 & $36.5-49.9$ & 43.3 & 3.22 \\
\hline Body width opercle & 53.3 & 243 & $39.8-67.8$ & 56.6 & 4.21 \\
\hline
\end{tabular}

ported by Garman (1890), an examination of the syntypes of $L$. varia indicated that these characters fall within the range of variation found in L. proxima. The two species are, thus, considered synonymous, with $L$. proxima utilized because it appears first in Garman's publication.

The color pattern described by Garman (1890) to characterize Laemolyta nitens dark longitudinal stripe, dark spots along the lateral line, and the presence in some specimens of narrow, dark, vertical bars and faint dark spot on the caudal peduncle also occurs in some specimens of L. proxima (Fig. 22). This, however, falls within the color pattern variation in this species. The comparison of meristic and morphometric data between the two nominal species failed to reveal any significant difference, and $L$. nitens is, thus, placed as a junior synonym of $L$. proxima .

Lasso (1992) reported Laemolyta proxima from the río Suapare (tributary of the río Orinoco, Venezuela). Two out of the 3 specimens in the lot that served as the basis of that record (MHNLS 5512) were examined. One specimen proved to be L. taeniata and the other L. orinocensis. The third specimen, probably the one illustrated in the paper, also looks very much like L. taeniata, because of the clearly visible dark longitudinal stripe, and the whitish areas on the scales above the lateral line that form forming light stripes and which are characteristic of this species.

Data from Santos \& Jégu (1996) indicate that Laemolyta proxima is found in floodplain lakes in large shoals during certain parts of the year, sometimes occurring together with L. garmani. Those authors note that L. proxima is fished commercially. The species is omnivorous, but feeds mainly on insect larvae and vegetable material (Santos, 1982). It is widely distributed through the Amazon Basin including Peru.

In the original description several specimens were designated syntypes of Anostomus (Schizodontopsis) proxima. The specimen in MCZ 19331 was examined and is herein designated as the lectotype.

\section{Laemolyta taeniata (Kner, 1859)}

(Fig. 23)

Schizodon taeniatus Kner, 1859: 159 [original description, type-locality: Brazil, rio Guaporé, Mato Grosso]; Fowler, 1942:214 [listed]; Eschmeyer, 1998: 1643 [catalog].

Anostomus taeniatus: Günther, 1864: 304 [brief description, rio Capim]; Garman, 1890: 18 [identification key, description, distribution]; Regan, 1905: 189 [listed].

Laemolyta taeniata Cope, 1872: 259 [designation of type species]; Eigenmann \& Eigenmann, 1891: 50 [listed]; Fowler, 1906: 322 [brief description, based on Cope's material]; Eigenmann, 1910: 425 [listed]; Fowler, 1942: 214, fig. 40 p. 213 [catalog, Peru]; Myers, 1950: 197 [diagnosis, type-locality]; Fowler, 1950: 209 [synonymy, distribution]; Knöppel, 1972: 234 [stomach contents]; Géry, 1974: 150 [supplementary description, identification key]; Ortega \& Vari, 1986: 12 [catalog]; Santos \& Jégu, 1989: 167, fig. p.196 [redescription], 1996: 161, fig. 10, p.178 [rio Uatumã (Amazon Basin), INPA's material listed]; Garavello \& Britski, 2003: 73 [catalog]; Lasso et al., 2004:105-195 [list of species and distribution].

Anostomus (Schizodontopsis) taeniatus: Borodin, 1931: 4546 [synonymy, diagnosis, comparative analysis of characters].

Anastomus [error] taeniatus: Fowler, 1942: 214 [listed].

Laemolyta taeniata taeniata: Géry, 1964: 466 [identification key].

Anostomus (Laemolyta) taeniatus: Géry, 1977: 179 [identification key, distribution].

Laemolyta proximus: Lasso, 1992: 15, fig. 4 p. 22 [in part, only specimen $143.9 \mathrm{~mm}$ SL in MHNLS 5512].

Laemolyta taeniatus: (Kner, 1854): Taphorn et al., 1997:55100 [catalog].

Material examined. 213 specimens (54.9-288.8 mm SL). Brazil. Mato Grosso: rio Guaporé, Natterer, NMW 81379: 2, 1 lectotype (by present designation), $159.4 \mathrm{~mm}$ SL. Rio Guaporé, Natterer, NMW 62875, 1 paralectotype, 177.3 mm SL. Bolivia. Beni: backwater slough of río Itenez, $10 \mathrm{~km}$ SE of Costa Marques, MamoréMadeira Amazon drainage, UMMZ 205215, 6 of 15, 43.2-69.5 mm SL. Brazil. Amazonas: rio Negro, Camanaos Rapids, below São Gabriel, CAS 116291, 1, 188.3 mm SL. Rio Negro, CAS 116289, 1, $99 \mathrm{~mm}$ SL. Rio Uatumã, Presidente Figueiredo, igarapé Arraia, Balbina Dam, INPA 10015, 1, 172.9 mm SL. Presidente Figueiredo, rio Uatumã, igarapé Arraia, Balbina Dam, INPA 10016, 2, 212-214 $\mathrm{mm}$ SL. Rio Amazonas, ilha do Careiro, igarapé da Terra Nova, INPA 10812, 1, 166.3 mm SL. Mouth of Paraná Urucará, MZUSP 5764, 1, 249.6 mm SL. Lago Manacapuru, MZUSP 58851 of 2, $163 \mathrm{~mm}$ SL. Igarapé Jaraqui, left bank of rio Negro, MZUSP 6189, 8 of 10, 198.7-235.9 mm SL. Rio Canumá, MZUSP 7057, 4 of 5, 110.3-181.3 mm SL. Rio Negro, Tapera, MZUSP 43363, 1, 207.2 mm SL. Rio Negro, Tapera, MZUSP 59056, 9, 166.4-221.2 mm SL. Rio Negro, Paricatuba, MZUSP 45559, 1, $197.3 \mathrm{~mm}$ SL. Pond on island in rio Negro, Paricatuba, MZUSP 62116, 1, $63.8 \mathrm{~mm}$ SL. Rio Negro, below rio Daraá, MZUSP 29158 1, $66.3 \mathrm{~mm} \mathrm{SL}$ and MZUSP 31266, 1, 79.4 mm SL. Rio Negro, Barcelos, MZUSP 29189, 10, 74-92.3 mm SL and MZUSP 29192, 1, $111.5 \mathrm{~mm}$ SL. 


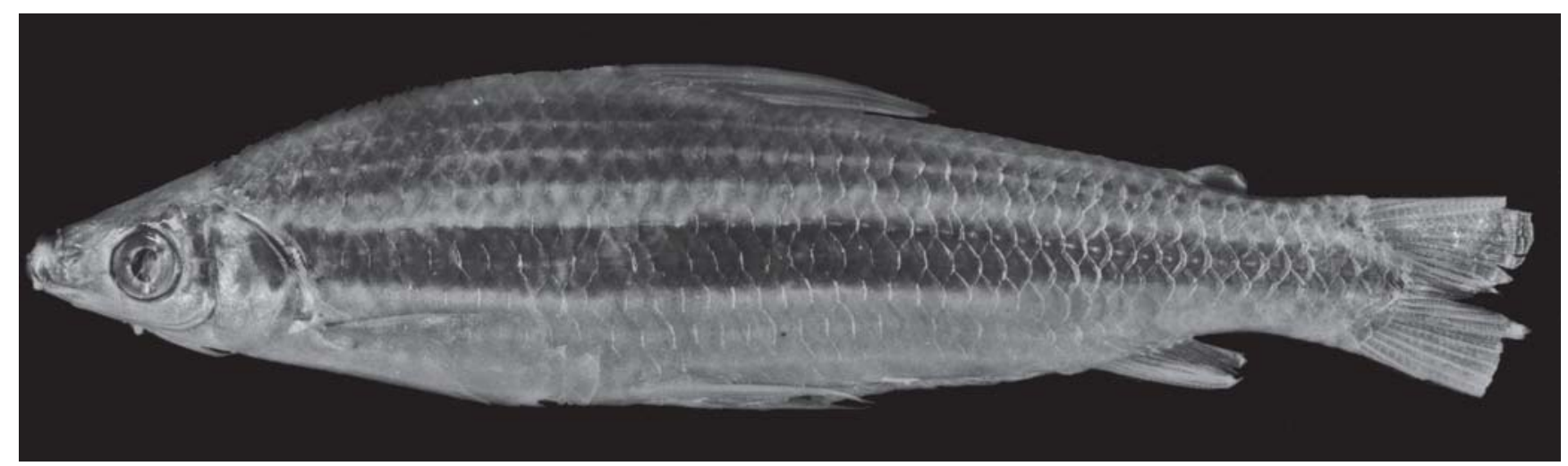

Fig. 23. Laemolyta taeniata, lectotype, NMW 81379: 2, 159.4 mm SL; Brazil, rio Guaporé.

Rio Negro, above rio Urubaxi, central lake in ilha Buiu-Açu, MZUSP 29190, 14 of 19, 73.5-116.7 mm SL. Rio Negro, below Daraá, MZUSP 32417, 2 of 3, 122.6-177.7 mm SL. Rio Negro, lake in ilha de Tamaquari, MZUSP 32417, 2 of 3, 198.3-241.7 mm SL. Junction between rio Negro and Arirará, MZUSP 32418, 1, $205.6 \mathrm{~mm}$ SL. Rio Negro above Barcelos, MZUSP 32419, 4, 148.7-214.4 mm SL. Rio Negro, Marauiá, Cachoeira Bicho-Açu, MZUSP 32420, 3 of 5, 177.9-188.7 mm SL. Rio Negro, igapó in Anavilhanas, MZUSP 60184, 2, 200.4-201.9 mm SL. Rio Negro, lago do Prato, Anavilhanas, MZUSP 60186, 1, $231.8 \mathrm{~mm}$ SL. Rio Marauiá, lake on edge of river, MZUSP 60187, 10 of 11, 130.7-227.6 mm SL. Rio Negro, igapó in Anavilhanas, MZUSP 61641, 1, 145.8 mm SL. Rio Negro, Anavilhanas, MZUSP 63611 1, $212.1 \mathrm{~mm}$ SL. Rio Amazonas, lago Puraquequara MZUSP 63612, 1, 75.9 mm SL. Goiás: São Domingos MZUSP 3850, specimen damaged (not included in analysis). Rio Tocantins, below the dam of Serra da Mesa, SM 19-221 specimen examined (not included in analysis). Mato Grosso: rio Guaporé, 5 $\mathrm{km}$ above Costa Marques, INPA 11187, 5, 70.3-73.4 mm SL. Rio Aripuanã, ilha do Castanhal, INPA 14275, 1, 220.5 mm SL. Rio Alegre tributary of rio Guaporé about $30 \mathrm{~km}$ above Vila Bela da Santíssima Trindade, MZUSP 36928, 5, 113.6-214.8 mm SL, MZUSP 37468, 4, 175.1-209 mm SL. Rio Guaporé, nearby Vila Bela da Santíssima Trindade, MZUSP 37438, 10 of 15, 144.2249.6 mm SL. Pará: Curuá-Una (km 80), INPA 772, 3, 168.8-288.8 mm SL. Rio Tocantins, igarapé Canoal, above Tucuruí waterfall, INPA 1598, 1, 142 mm SL. Lago Morateiro, Itupiranga (Tocantins), INPA 1600, 3, 88.5-93.4 mm SL. Rondônia: rio Jaci-Paraná, about $40 \mathrm{~km}$ above town of Jaci-Paraná (near Três Marias), INPA 10603, 1, 194.7 mm SL. Rio Pacaás Novos, tributary of rio Mamoré, about $15 \mathrm{~km}$ above Guajará-Mirim, INPA 12223, 1, $99.6 \mathrm{~mm}$ SL. Rio Jamari, INPA 12230, 1, 72.4 mm SL. Rio Jamari, lago da Espanha, about $15 \mathrm{~km}$ below Samuel Dam, INPA 15206, 1, 179 mm SL. Rio Jamari, lago da Espanha, about $15 \mathrm{~km}$ below Samuel Dam, Candeias do Sul, INPA 15207, 1, 126.2 mm SL. Rio Guaporé, mouth of rio São Domingos, igapó, Costa Marques, INPA 15208, 1, 175.9 mm SL. Rio Canaã, about $10 \mathrm{~km}$ above Ariquemes, lago Fortaleza, Ariquemes, INPA 15209, 5, 161.2-204 mm SL. Rio Pacaás Novos, Guajará-Mirim, INPA 15213, 5, 109.9-217.5 mm SL. Rio Trombetas, Oriximiná, MZUSP 5423, 12 of 15, 190.4-226.2 mm SL. Oriximiná, MZUSP 21191, 1, 73.6 mm SL. Rio Capim near Ananindeua, MZUSP 21202, 1, 190 mm SL. Lago Maria Preta, rio Capim, MZUSP 21213, 1, 58.3 mm SL. Lago Jurunundeua, rio Capim, MZUSP 21218, 4, 86.8-92.9 mm SL. Ilha da Barreirinha, rio Tapajós, São Luís, MZUSP 21226, 10, 84.4-94.4 mm SL and MZUSP 22106, 3, 105.5-124.7 mm SL. Igarapé Açu, Aveiro, MZUSP 21361, 8, 104.2-133.5 mm SL. Lago Bernardino, near Vila Badajós, rio Capim, MZUSP 63613, 1, 96.7 mm SL. Lago Jacaré, rio Trombetas, MZUSP 49320, 3, 162.9-203.8 mm SL. Rio Trombetas, island in mouth of lago Erepecu, Trombetas Biological Reserve, MZUSP 62412, 1, 145.7 mm SL. Rondônia: rio Machado, Santo Antônio, lago do Mucuim, MZUSP 61977, 1, 68.6 mm SL. Colômbia. Guainía: río Inírida drainage: Morizal Garza, ca 10 km NE from mouth of río Papunava, río Orinoco basin, NRM 27510, 1 of 2, $60.5 \mathrm{~mm}$ SL. Venezuela. Laja Vendita: río Casiquiare, Amazonas, CAS 20173, 1, 87.8 mm SL, CAS 116288, 1, 84.1 mm SL. Laguna, $2 \mathrm{~km}$ SE of Caño la Pica, Apure, MHNLS 4231, 2 of 7, $69.3 \mathrm{~mm}$ SL. Laguna, 2 km SW of Caño La Pica (Paso Grande), D. Medina, MHNLS 5163, 1, 81.7 mm SL. Río Suapure, Rabo de Cochino, Pijiguaos, Bolívar, MHNLS 5512, 1 of 3, 143 mm SL. Laguna Cejal, floodplain, caño Mato, tributary of río Caura, Bolívar, MHNLS 12831, 2, 99.9-102.5 mm SL. Laguna los Garzones, floodplain, caño Mato, tributary of río Caura, MHNLS 13059, 1, $92.1 \mathrm{~mm}$ SL.

Diagnosis. Laemolyta taeniata is the only species in the genus having 5 longitudinal scale rows from the lateral line to the origin of the dorsal fin (vs. 4 and 6-8 in the remaining species). Its color pattern is similar to that of L. garmani and L. orinocensis, but it can be distinguished from L. garmani by the presence of a dark, midlateral longitudinal stripe and the more conspicuous, narrow light stripes above the lateral line and from L. orinocensis in having fewer scales along the lateral line (42-46 vs. 47-52).

Table 6. Morphometrics of Laemolyta taeniata.

\begin{tabular}{lccccc}
\hline Character & Lectotype & N & Range & Mean & SD \\
\hline Standard length (mm) & 159.4 & 205 & $54.9-288.8$ & 147.4 & - \\
& Percents of standard length & & \\
Preanal distance & 80.5 & 205 & $77.2-85.0$ & 80.1 & 1.42 \\
Preventral distance & 47.1 & 205 & $44.3-50.1$ & 47.0 & 1.10 \\
Prepectoral distance & 23.1 & 205 & $19.1-26.8$ & 22.5 & 1.42 \\
Predorsal distance & 46.2 & 205 & $41.1-48.4$ & 44.5 & 0.96 \\
Body depth & 25.1 & 205 & $18.8-27.5$ & 22.8 & 1.98 \\
Caudal-peduncle depth & 10.1 & 205 & $7.50-10.2$ & 8.80 & 0.60 \\
Caudal-peduncle length & 10.4 & 205 & $9.20-13.9$ & 11.7 & 0.92 \\
Dorsal-fin length & 25.7 & 205 & $19.8-27.5$ & 24.0 & 1.61 \\
Ventral-fin length & 17.9 & 205 & $14.3-19.0$ & 16.8 & 1.05 \\
Pectoral-fin length & 16.2 & 205 & $13.2-17.8$ & 15.6 & 0.80 \\
Anal-fin length & 12.3 & 205 & $10.0-14.3$ & 12.0 & 0.74 \\
Head length & 21.9 & 205 & $19.4-26.0$ & 22.0 & 1.35 \\
Dorsal-fin base length & 13.7 & 205 & $11.5-15.4$ & 13.6 & 0.59 \\
Anal-fin base length & 8.50 & 205 & $7.10-11.6$ & 8.60 & 0.58 \\
& Percents of head length & & \\
Eye diameter & 27.1 & 205 & $26.0-36.6$ & 30.7 & 2.50 \\
Antorbital length & 37.0 & 205 & $31.0-41.3$ & 36.7 & 1.76 \\
Interorbital distance & 42.8 & 205 & $34.4-47.3$ & 40.3 & 3.30 \\
Body width opercle & 53.1 & 205 & $47.5-62.9$ & 55.4 & 3.31 \\
\hline
\end{tabular}


Description. Meristic and morphometric data presented in Table 6. Body moderately large $(\mathrm{SL}=54.9-288.8 \mathrm{~mm})$. Dorsal profile of body almost straight and posterodorsally inclined from anterior tip of snout to end of occipital spine, slightly convex from that point to origin of dorsal fin, straight and posteroventrally inclined along dorsal-fin base and straight or slightly convex from base of posterior-most end of dorsalfin ray to origin of adipose fin.

Gill rakers on dorsal limb of first gill arch 9-12 and 11-15 on ventral limb.

Perforated scales on lateral line 42-46 (44*, usually 44, Table 2). Longitudinal scale rows from lateral line to dorsalfin origin 5; scales rows from lateral line to anal-fin origin 4-5 (4*, usually 4). Predorsal scales 11-13 (12*, usually 12) and usually regularly arranged. Scales rows around caudal peduncle 15-17 (16*, usually 16).

Dorsal fin rays ii,9-12 (11*, usually 12$)$; distal margin of fin slightly rounded. Anal fin short, slightly falcate, with ii, 79 (8*, usually 8 ) rays. Pectoral fin rays i, 10-16 (12, usually 13 ). Pelvic fin rays i, $8-9$ ( $8^{*}$, usually 8$)$; distal margin of fin truncate. Vertebrae 40-41 (41*, usually $41 \mathrm{~N}=5)$.

Color in alcohol. Dorsal region of body generally dark, dark coloration extending ventrally to 1 longitudinal scale row above lateral line. Conspicuous, dark, longitudinal stripe extending from tip of snout to caudal peduncle. Stripe narrower on snout and caudal peduncle. Scales above lateral line with central posterior areas whitish and forming narrow light stripes or linear light dots.

Distribution. Amazon and Orinoco basins (Fig. 10).

Remarks. In the original description three specimens were designated syntypes of Schizodon taeniatus. Specimen NMW 81379:2 is herein designated the lectotype.

Laemolyta taeniata reaches the largest size among its congeners and it is the second most widely distributed member of the genus in the Amazon basin, being particularly common in the central Amazon and upper rio Madeira basin. It has also been recorded in the río Orinoco basin where it has been confused with $L$. orinocensis.

Data from Santos \& Jégu (1996) indicate that $L$. taeniata is usually found in lakes and main river channels where it forms large migratory shoals in company of species of other genera such as Leporinus fasciatus and L. agassizi.

Although not included in the list of examined material, specimens from São Domingos, (MZUSP 3850, specimen damaged) and rio Tocantins, below the dam of Serra da Mesa, Goiás (SM 19-221 da Universidade Federal do Rio de Janeiro, specimen examined, but not included in analysis) were examined.

\section{Acknowledgments}

For the loan of specimens, information, assistance and sending photographs we thank Barbara Brown (AMNH), John Lundberg and Mike Littmann (ANSP), Carlos Lasso (MHNLS),
Claude Weber (MHNG), Darrell Siebert (BMNH), David Catania (CAS), Donald Taphorn (MCNG), Douglas Nelson (UMMZ), Francisco Provenzano (MBUCV), Helmut Wellendorf (NMW), Guy Duhamel (MNHN), José L. de Figueiredo and Osvaldo Oyakawa (MZUSP), Karsten Hartel (MCZ), Lúcia Rapp. Py-Daniel and Geraldo M. dos Santos (INPA), Mary-Anne Rogers (FMNH), Renata Bartolette and Maria Cristina Ramos (UFRJ), Sven Kullander (NRM), and Susan Jewett and Sandra Raredon (USNM). Thanks to Franklin de A. Sterman (Faculdade de Medicina Veterinária da Universidade de São Paulo) for making his laboratory available for preparing radiographs of Laemolyta species, Monica Toledo-Piza and Osvaldo Oyakawa were very helpful throughout the development of this study. Photographs of specimens were taken by José C. Nolasco. The distribution maps are based on a map of South America prepared by M. Weitzman. For reviewing previous versions of this manuscript we thank Richard P. Vari and Monica Toledo-Piza. The senior author received financial support through a scholarship (grant 99/07565-4) provided by the Fundação de Amparo à Pesquisa do Estado de São Paulo (FAPESP). This study was developed at the Seção de Peixes of MZUSP, which provided work space and access to various facilities.

\section{Literature Cited}

Ahl, V. E. 1937. Zwei neue fishname innerhalb der südamerikanischen Familie Anostomidae. Sitzungsberichte der gesellschaft naturforschender freunde zu Berlin. 1937: 136.

Böhlke, J. E. 1953. A catalogue of the type specimens of Recent fishes in the Natural History Museum of Stanford University. Stanford Ichthyological Bulletin, 5: 1-167.

Böhlke, J. E. 1958. Studies on fishes of the family Characidae. A report on several extensive recent collections from Ecuador. Proceedings of the Academy of Natural Sciences of Philadelphia, 110(14): 1-121.

Borodin, N. A. 1931. On the genus Anostomus (Family Characinidae). Bulletin of the Museum of Comparative Zoology, 72(2): 37-52.

Cope, E. D. 1872. On the fishes of the Ambiyacu River. Proceedings of the Academy of Natural Sciences of Philadelphia, 1872: 250298.

Eigenmann, C. H. 1910. Catalogue of the fresh-water fishes of tropical and south temperate America. In: Scott, W. B. (ed.) Reports of the Princeton University Expeditions to Patagonia, 18961899. Zoology. Catalogue 3(4): 375-511.

Eigenmann, C. H. \& R. S. Eigenmann. 1891. A catalogue of the fresh-water fishes of South America. Proceedings of the United States National Museum, 14(842): 1-81.

Eschmeyer, W. N. (Ed.). 1998 . Catalog of fishes. California Academy of Sciences, San Francisco, 2905 p.

Fink, W. L. \& S. H. Weitzman. 1974. The so called cheirodontin fishes of Central America with descriptions of two new species (Pisces: Characidae). Smithsonian Contributions to Zoology, 172: 1-46.

Fowler, H. W. 1906. Further knowledge of some Heterognathous fishes. Part I. Proceedings of the Academy of Natural Sciences of Philadelphia, 58: 293-351.

Fowler, H. W. 1942. Los peces del Peru. Boletin del Museo de 
Historia Natural "Javier Prado", 6 (21): 206-222.

Fowler, H. W. 1950. Os peixes de água doce do Brasil. Arquivos de Zoologia, do Estado de São Paulo, 6(1): 205-214.

Garavello, J. C. 1994. Descrição de uma nova espécie do gênero Schizodon Agassiz da bacia do rio Uruguai, Brasil (Ostariophysi, Anostomidae). Comunicações do Museu de Ciências e Tecnologia da PUCRS, Sér. Zool., 7: 195-203.

Garavello, J. C. \& H. A. Britski. 1990. Duas novas espécies do gênero Schizodon Agassiz da bacia do alto Paraná, Brasil, América do Sul (Ostariophysi, Anostomidae). Naturalia, 15: 153-170.

Garavello, J. C. \& H. A. Bristki. 2003. Family Anostomidae. Pp. 71-84. In: R. E. Reis, S. O. Kullander \& C. J. Ferraris (Eds.). Check list of the freshwater fishes of South and Central America. Edipucrs, Porto Alegre. 729 p.

Garman, S. 1890. On the species of the genus Anostomus. Bulletin of the Essex Institute, 22: 15-23.

Géry, J. 1961. Contributions à l'ètude des Poissons Characoides. Bulletin of Aquatic Biology, 2(19): 93-111.

Géry, J. 1964. Poissons Characoides nouveaux ou non signalés de l'Ilha do Bananal, Brésil. Vie Milieu Suppl. 16: 447-471, pls 1-4.

Géry, J. 1974. Notes sur quelques Anostomidae (Pisces, Characoidei) du Bassin Amazonien. Vie et Milieu (Ser. C): Biologie Terrestre, 23(1): 143-175, Pl. 1.

Géry, J. 1977. Characoids of the World. Tropical Fish Hobbyist, New Jersey. 772 p.

Günther, A. 1864. Catalogue of the fishes in the British Museum. Vol. 5, Catalogue of the Physostomi, containing the families Siluridae, Characinidae, Haplochitonidae, Sternoptychidae, Scopelidae, Stomiatidae in the collection of the BritishMuseum, Trustees, London, xii+445 p.

Kner, R. 1859. Zur Familie der Characinen. III. Folge der Ichthyologische Beiträge. Denkschriften der Akademie der Wissenschaften in Wien, 17: 137-182, pls. 1-9.

Lasso, C. 1992. Composicion y aspectos ecologicos de la ictiofauna del bajo río Suapure, Serrania de Los Pijiguaos (Escudo de Guayana), Venezuela. Memórias de la Sociedad de Ciências Naturales La Salle, 52(138): 5-56.

Lasso, C. A., D. Lew, D. Taphorn, C. do Nascimiento, O. LassoAlcalá, F. Provenzano \& A. Machado-Allison. 2004. Biodiversidae ictiológica continental de Venezuela. Parte 1. Lista de especies y distribución por cuencas. Memoria Fundación La Salle de Ciencias Naturales, 159-160 (for 2003): 105-195.

Myers, G. S. 1950. Studies on South American freshwater fishes. II. The genera of anostomine characids. Stanford Ichthyological Bulletin, 3(4): 184-198.

Myers, G. S. \& A. L. Carvalho. 1959. A remarkable new genus of anostomin characid fishes from the upper rio Xingú in central Brazil. Copeia 1959(2): 1-150.

Ortega, H. \& R. P. Vari. 1986. Annotated checklist of the freshwater fishes of Peru. Smithsonian Contributions to Zoology, 437: 1-25.

Pearson, N. E. 1924. The fishes of the eastern slope of the Andes. I. The fishes of the rio Beni basin, Bolivia, collected by the Mulford Expedition. Indiana University Studies, 11: 29-30.
Regan, C. T. 1905. On drawings of fishes of the rio Negro. Proceedings of the Zoological Society of London, 1905: 189-190.

Santos, G. M. 1982. Caracterização, hábitos alimentares e reprodutivo de quatro espéciesde "aracus" e considerações ecológicas sobre o grupo no lago Janauacá (Characoidei) - AM. Acta Amazônica, 12(4): 713-739.

Santos, G. M. \& M. Jégu. 1989. Inventário taxonômico e redescrição das espécies de anostomídeos (Characiformes, Anostomidae) do baixo rio Tocantins, PA, Brasil. Acta Amazônica, 19(1): 159-213.

Santos, G. M. \& M. Jégu. 1996. Inventário taxonômico dos Anostomídeos (Pisces Anostomidae) da bacia do rio UatumãAM, Brasil, com descrição de duas espécies novas. Acta Amazônica, 26(3): 151-184.

Santos, G. M, M. Jégu \& B. de Merona. 1984. Catálogo de peixes comerciais do baixo rio Tocantins. Projeto Tucuruí. EletronorteCNPq-INPA, Manaus. 83 p.

Steindachner, F. 1879. Beiträge zur Kenntniss dês Flussfische Südamerika's. Denkschriften der Akadmie der Wissenschaften, 39: 153-154.

Taphorn, D., R. Royero, A. Machado-Allison \& F. Mago-Leccia. 1997. Lista actualizada de los peces de agua dulce de Venezuela. Pp. 55-100. In: E. La Marca (ed.).Vertebrados Actuales y Fosiles de Venezuela. Serie Catálogo Zoológico de Venezuela. Museo de Ciencia y Tecnología de Merida, Venezuela.

Taylor, W. R. \& G. C. Van Dyke. 1985. Revised procedures for staining and clearing small fishes and other vertebrates for bone and cartilage study. Cybium, 9(2): 107-119.

Ulrey, A. B. 1895. The South American Characinidae collected by Charles Frederick Hartt. Annals of the New York Academy of Sciences, 8: 257-300.

Vanzolini, P. E. \& N. Papavero. 1968. Indice dos Topônimos contidos na carta do Brasil 1:1.000.000. São Paulo, Fapesp. 111 p.

Vari, R. P. 1983. Phylogenetic relationships of the families Curimatidae, Prochilodontidae, Anostomidae and Chilodontidae (Pisces: Characiformes). Smithsonian Contributions to Zoology, 378: $1-60$.

Vari, R. P. \& J. C. Howe. 1991. Catalog of type specimens of Recent fishes in the National Museum of Natural History, Smithsonian Institution, 1: Characiformes (Teleostei: Ostariophysi). Smithsonian Contributions to Zoology, 517: 1-52.

Weber, C. 1998. Catalogue révisé des types primaires de la collection ichthyologique du Muséum d'histoire naturelle de la Ville de Genéve (MHNG). Revue Suisse Zoologie, 105(1): 3-14.

Winterbottom, R. 1980. Systematics, osteology and phylogenetic relationships of fishes of the Ostariophysan subfamily Anostominae (Characoidei, Anostomidae). Life Sciences Contribution, 123: 1-112.

Received August 2005 Accepted January 2006 